\title{
Phenolic compounds as nutraceuticals or functional food ingredients
}

\author{
Cristina Caleja ${ }^{1,2,3}$, Andreia Ribeiro ${ }^{1,2}$, Maria Filomena Barreiro², Isabel C.F.R. Ferreira ${ }^{1, *}$ \\ ${ }^{1}$ Mountain Research Centre (CIMO), ESA, Polytechnic Institute of Bragança, Bragança, Portugal \\ ${ }^{2}$ Laboratory of Separation and Reaction Engineering (LSRE), Associate Laboratory LSRE/LCM, IPB, \\ Bragança, Portugal. \\ ${ }^{3}$ REQUIMTE/LAQV, Faculty of Pharmacy, University of Porto, Porto, Portugal
}

*_Author to whom correspondence should be addressed (e-mail: iferreira@ipb.pt telephone+351-273303219; fax +351-273-325405).

\begin{abstract}
Background: Nowadays, the functional foods represent one the most promising, interesting and innovative areas in the food industry. Various components are being added to foods in order to render them functional. Methods: One example of these components are plant naturally occurring phenolic compounds, which are associated with a high antioxidant capacity and thus with benefits in relation to human health. Results: However, despite the huge number of scientific studies and patents on this topic and their natural presence in foods, namely in the ones from plant origin, there are still few marketable products enriched with these compounds. The commercialization of this type of functional products needs to go through various regulations, proving that they are safe and present the ascribed health benefits, conquering the target audience. In this review the growing interest of industry and consumers' appetence for functional foods and nutraceuticals is highlighted, focusing especially phenolic compounds. Conclusion: Although several published works show the multitude of bioactive properties of these compounds, ensuring their use as bioactive ingredients in food, they present inherent stability issues needing to be solved. However, considerable research is presently ongoing to overcome this problem, making viable the development of new products to be launched in the market.
\end{abstract}

Keywords: Phenolic compounds; nutraceuticals; functional foods; health benefits; consumers.

\section{INTRODUCTION}

The scientific community and the food industry have developed an increasing interest for functional and nutraceutical properties of some nutrients and natural compounds, in viewing of their incorporation in added-value foodstuffs. These enrichments can use natural sources from plant, mushroom or animal origin, but also synthetic compounds with improved biological activities. Some examples of bioactive ingredients are vitamins, amino acids, fibers, fatty acids, and phenolic compounds (PC) [1]. The bioactive ingredients obtained from natural sources have been used since ancient times all over the world with the conviction that guarantee medicinal properties in fighting certain diseases [2,3].

Phenolic acids, flavonoids and stilbenes are some of the PC classes, widely distributed among medicinal herbs and dietary plants. These compounds present a broad range of bioactivities such as antioxidant, antimicrobial, anti-inflammatory, antitumoral and hepatoprotective effects. Some PC exhibit 
high antioxidant activity as individual compounds, while others, depend on synergisms to undergo bioactive effects [4]. The antioxidant activity of these compounds is related with their chemical structure, generally depending on hydroxyl groups' number and position, glycosylation or other types of substitution [5]. Furthermore, PC are involved in the neutralization of reactive species that attack cell molecules and in several diseases prevention related to oxidative and nitrosative stress such as cancer, cardiovascular diseases, atherosclerosis, neurological disorders, hypertension, and diabetes mellitus, among others [4].

There are also many studies describing the antifungal activity of PC, expressed through an interaction with the lipid bilayer of the fungi cell membrane (disruption of the membrane integrity or intercalation into cell wall and/or DNA - Deoxyribonucleic Acid) [6]. These compounds have also shown antimicrobial activity, by delaying or inhibiting the growth of pathogenic and/or toxin-producing microorganisms in food, as also by minimizing the incidence of foodborne diseases caused by food spoilage bacteria and fungi [7]. The numerous scientific studies with PC also described their antiinflammatory properties $[8,9]$. During the inflammation process it is observed the formation of various reactive oxygen species (ROS) and reactive nitrogen species (RNS) that result in increased activity of pro-inflammatory agents. The PC have ability to reduce or prevent the prejudicial effects in human organism through the reduction of pro-inflammatory enzymes [10].

Cancer is a global concern which causes millions of deaths each year, even in the most developed countries [11]. Despite major advances in the treatment of patients with cancer these remain insufficient to reduce suffering and mortality [12]. In traditional medicine, the plants represent an important ally in the treatment of various diseases. Currently, natural compounds represent an important fraction in the composition of new anticancer drugs developed by the pharmaceutical industry $[13,14]$. Several studies have concluded that bioactive ingredients from plants may have anticancer effects in cell lines but also in murine models, including being more efficient than synthetic compounds [15]. There are several toxicity problems associated with the use of synthetic molecules in the treatment of cancer. Alternatively, some natural compounds isolated from plants can be administered without any side effect or toxicity to patients [15]. The potential antitumoral effects of PC have been intensively studied, both with tumor cell lines and by using in vivo models and human trials [15]. PC have shown the capacity to induce apoptosis by arresting cell cycle, regulate carcinogen metabolism and ontogenesis expression, inhibit DNA binding and cell adhesion, migration, proliferation or differentiation, and block signaling pathways [16]. Additionally, PC have been intensively studied in regard to their hepatoprotective capacity against chemically induced damage, either in vivo or in vitro. These compounds seem to overcome liver injuries often caused by oxidative reactions that promote lipid peroxidation in hepatic tissues; among these constituents, flavonoids and phenolic acids have received special attention for their high antioxidant activity supporting the observed hepatoprotective effects [17].

Due to their characteristics, foods rich in PC have been considered functional foods. Although the existence of earlier reports (1985-1999), a significant growing interest for this type of products, either from academia (through research articles and scientific reviews) or industry (through patents), was observed since 2000, indicating an increasing tendency (Figure 1). 
In this review article, the sector of functional foods and nutraceuticals was analyzed, highlighting the particular case of the use of PC as bioactive ingredients, either in functional foods or in nutraceutical formulations. Examples of products already available in the market will be also given.

\section{THE GROWING SECTOR OF FUNCTIONAL FOODS AND NUTRACEUTICALS}

\subsection{Definitions}

The term "functional food" first appeared in the $80 \mathrm{~s}$ in Japan in reference to food products enriched with special components that have beneficial physiological effects $[18,19]$.

A food can be classified as "functional" if, beyond adequate nutritional effects, it demonstrates benefits in one or more target functions in the human body relevant to improve health and well-being and/or to reduce risk disease. These foods can be natural or unmodified, or foods to which a component has been added or removed by technological means. They can be naturally ingested in diet. Thus, functional foods can be classified as: 1) Non-altered products, foods which naturally contain a high level of nutrients/health promoting compounds (e.g. eggs with increased omega-3); 2) Fortified products, foods in which components content is increased (e.g. fruit juices fortified with vitamin C); 3) Enriched products, foods to which a component with certain benefits was added (e.g. margarine with plant sterol ester, pro and prebiotics); 4) Altered products, i.e. foods in which a specific component was removed or substituted (e.g. addition of fibers as fat releasers in meat or ice cream products) [20-22].

Presently there is no definition or legislation universally accepted for functional foods [23]. However, this is one of the most interesting and active research and innovation areas for the food industrial sector [24]. Its market share is growing worldwide, and new products are being continuously launched [19]. Some commercial products with beneficial health functions can be already found; among them the most demanded by the consumers are: probiotic liquid yogurt containing Lactobacillus casei Imunitass $^{\circledR}$ cultures (brand Actimel $^{\circledR}$ from Danone $^{\circledR}$, France), solid yogurt with Bifidus ActiRegularis ${ }^{\circledR}$ (brand Activia ${ }^{\circledR}$ from Danone ${ }^{\circledR}$, France), snacks and cereal bars with natural fibers and extra minerals and vitamins (Snack brand Fibra ${ }^{\circledR}$ from Celigüeta ${ }^{\circledR}$, Spain), dairy drink with L. casei Shirota (brand Yacult ${ }^{\circledR}$ from Yacult ${ }^{\circledR}$, Japan) and yogurt containing pre- and probiotics and omega-3 (brand Vitality ${ }^{\circledR}$, Müller $^{\circledR}$, Germany).

Among others, dairy products have many reported health benefits. They are widely consumed and appreciated by consumers and, thus, represent an important vehicle for functional foods development. Moreover, the dairy industry is considered one of the most important and dynamic sectors of the food industry. This sector is in permanent innovation trying to develop new products with added value. Accordingly, an increasing variety of new dairy products has been observed to satisfy consumer's demand for healthier products, including low-fat (e.g. skimmed and semi-skimmed milk) and the highprotein content ones [25].

In turn, nutraceuticals can be defined as diet supplements containing bioactive compounds or extracts, prepared from raw matrices and used in unit dosage forms such as tablets, capsules or liquids. Thus, the bioactive agent is in this case more concentrated, and otherwise, it cannot be obtained from the normal food intake to present positive physiological effects on the human body [26,27]. Nowadays, the 
use of nutraceutical formulations in dietary supplements as a complement to prevent some diseases is very common [28]. Some authors classified nutraceuticals in traditional (substances naturally contained in foods) and non-traditional (substances added to foods by bio-engineering actions) [29]. Nutraceuticals concept is relatively recent, only appearing in the $90 \mathrm{~s}$, but consumer's demand for new, better and safer food products is pressing food industry for a constant innovation and product's offer increase [30].

The processing of nutraceuticals can follow four steps: pretreatment (includes homogenization, grinding, milling, maceration, and drying), extraction (in which the selection of a method depends of factors such as the source and type of bioactive compound to be extracted, desired recovery and operational requirements), isolation/purification, and encapsulation [31].

When processed under controlled conditions (i.e. under moderate temperature and pressure, and by avoiding light exposure), nutraceuticals can suffer minor deterioration, nevertheless extreme $\mathrm{pH}$ conditions or enzymes presence, typical of intestinal tract, can significantly affect their bioavailability $[32,33]$.

It is a common pitfall the confusion between nutraceuticals and functional foods definition; even in the literature a nutraceuticals is defined as any food or part of it as long as their beneficial health and nutritional claims can be proved scientifically [28]. However, some authors consider nutraceuticals as components that are often consumed in unit dose forms such as tablets, capsules or liquids [27,34]. Sometimes nutraceuticals and functional foods are produced with the same ingredients but in different forms [35].

Nowadays, foods that indicate improvement of consumer's health have to go through a large control mainly in what concerns labeling information. The European Union (EU) is facing, since 2012, new legislation that requires a rigorous standard of scientific evidence for making health claims on foods, beverages and dietary supplements $[34,36]$. However, these foods are still not included in a specific food category [37]. On the other hand, in the United States of America (USA), Food and Drug Administration (FDA) defines the products categories depending on its characteristics obeying several safety issues, health claims, labelling and good manufacturing practices [38].

\subsection{Hot scientific topics and consumer's increasing demand}

Behavioral and socio-demographic trends, particularly the existence of different eating habits motivate the existence of different national policies to promote public health. This, together with differences related to cultural traditions, constitute the main challenges towards the successful introduction of functional products on the market. Therefore, for a better consumer's acceptance a strong enlightenment about "functional food" concept is needed. Some studies have shown that cognitive, motivational and attitudinal determinants of consumer's acceptance of functional foods vary considerably in different countries [39]. However, there has been a huge change in eating habits, i.e., in addition to the nutritional and sensory properties, food seems to play an important role in health maintenance and disease prevention [40,41]. Therefore, functional foods have gained prominence, becoming its development a hot research area for both academia and industry [36].

Functional foods have been growing in the market over time. Some entities, like researchers and professionals, agree that the market for functional foods is achieving a raising growth worldwide 
[39,40,42]. Their global market was estimated at about 625 billion dollars in 2012 [43], being the three main markets represented by Japan followed by the USA and finally EU. These three markets contribute to $90 \%$ of total sales [19]. Apart from its pioneer role (functional foods started to be a reality in this country), Japan is also the strongest market worldwide; in only 10 years (1988-1998) more than 1700 functional food products were released [19,44]. This market showed an average growth rate of $9.6 \%$ per year during the $90 \mathrm{~s}$, and their related industry was estimated to a turnover of approximately 12 billion dollars in 2003 [39].

The USA has the second largest market for functional foods, with a turnover of 10.5 billion dollars in 2003. In this country the market share for functional foods is around $2-3 \%$ and is constantly growing

$[39,40]$. The ever-growing functional foods and drinks market increased 1.5 fold globally, reaching 24.2 billion dollars in 2010 and 29.8 billion dollars in 2014 [36].

Europeans still show some skepticism in relation to functional foods, partly due to suspected safety of these food products, but also because of their productive process [39]. The demand for functional foods in the EU varies due to food and cultural traditions, being higher in Northern Europe than in Mediterranean countries. United Kingdom (2.6 billion dollars), Germany (2.4 billion dollars), France (1.4 billion dollars) and Italy (1.2 billion dollars) stand as the main markets [19,39]. However, many other markets, such as Netherlands, Spain, Poland and Hungary, are experiencing high growth rates [199,39, 45-47].

In the EU, as well as in Japan, the market for functional foods is dominated by probiotics, and 370 products were launched worldwide in 2005 [48]. The lactic acid bacteria (LAB) and bifidobacteria are the most studied and used for new product development, for example in Italy, the most important product in functional food market is the called "health yogurt"; it represented in 2008 a growth rate of $6.3 \%$ per year, thus reaching 560 million euros of sales, corresponding to almost $4 \%$ of the whole Italian sector [19].

Functional foods have added benefits if compared to the traditional ones. The functionality of these foods is derived from the presence of bioactive ingredients. Typically, the functional ingredients incorporated into foods aimed at prevent some chronic diseases, as well as promote better physical and psychic well-being; therefore, health concerns are the most significant factors influencing consumers. According with Arvanitoyannis \& Houwelingen-Koukaliaroglou [49], people from different countries seek for different characteristics in food. Thus, Americans search primarily functional food for weight loss and cholesterol lowering, while EU, which comprises the major consuming countries, wants mainly health prevention food. In particular, United Kingdom consumes foods to promote bone and teeth health, Germany to enhance/stimulate the immunologic system and bone health; and lastly, in France, the functional foods are consumed to stimulate cholesterol lowering and generally increase resistance to disease.

\subsection{Main bioactive ingredients and food sectors}

The acceptance of a specific functional ingredient is intimately related to consumer's knowledge of its beneficial health effects. Thus, the functional ingredients known since a longer period, such as minerals, vitamins, fibers, and fatty acids reach considerably higher acceptance rates than the newer ones, 
such as PC. In this case, consumers do not recognize the health benefits associated to this last group $[22,25]$.

Vitamins and minerals are defined as nutrients and have recommended ingesting doses in order to produce the desired effect [50,51]. Vitamins are complex organic substances that are required in small quantities for a healthy body. With the exception of vitamin D, all other vitamins are not produced by the organism, having to be obtained through the diet. Vitamins play important biological functions, such as in the role of co-factors in enzymatic activity, as antioxidants or as pro-hormone [49]. Milaneschi et al [52] described that there is a correlation between vitamin $\mathrm{E}$ and the onset of depression in the elderly. This study was conducted with 531 women and 432 men aged from 65 years, being found a direct relationship between 25-hydroxyvitamin D deficiency and depression [25]. Dietary fibers are defined as nondigestible carbohydrates that are present in vegetal sources. The fibers can be classified as water soluble or insoluble, and may alter the nature of the gastrointestinal tract contents, changing the way nutrients and chemicals are absorbed. Examples such inulin and several other oligosaccharides stimulate bifidobacteria growth, increasing gut health (decreased intestinal transit) and immunity. Minerals are essential to body function, since they are involved in metabolic processes such as muscle contraction, nerve impulses transmission, water maintenance, acid-base balance, and catalysis of other biological reactions [49].

PC, compounds naturally present in plants, are among the most interesting bioactives due to its great antioxidant capacity associated with benefits in relation to human health, namely in the prevention of some common diseases [53]. This type of compounds have been widely studied in recent years, and further incorporated into different food matrices in order to render them functional $[54,55]$.

Currently, food industry has developed different fortified food products to meet consumer's demands, who are increasingly concerned with their feeding habits. Therefore, new functional food products have been developed by introducing the active ingredient at the correct dosage, and without changing organoleptic and texture properties, as appreciated by the consumers $[30,56]$.

Functional foods have been developed in virtually all food categories. Functional cereal components such as beta-glucan (mainly from oat and barley), have been used in dairy bakery industries to manufacture low-fat ice creams [57]. The bakery products still represent a small share in the functional foods industry (just over 13\% in 2000s), comparatively with dairy products, which holds the largest share of the functional food market [22,40]. However, a growth in this sector has been observed, and there are some successful examples in the market. This is the case of Unilever ${ }^{\mathbb{R}}$ that produced in 2003 the "Blue Band Goede Start ${ }^{\circledR} "$ as the first white bread enriched with functional elements (fiber, vitamins B1, B3 and B6, iron, zinc and inulin), only available on whole wheat bread [58].

Eggs, a fatty acids rich food highly appreciated by consumers, are another example that raised interest in the food industry to make them functional. In the United Kingdom, the Freshlay Foods ${ }^{\circledR}$ produced the VITA Eggs ${ }^{\circledR}$, described as eggs enriched with omega-3 fatty acids conjunctly with antioxidants and other vitamins (D, E, B12 and folic acid). Also in Belgium, there is a similar successful case: the Columbus ${ }^{\circledR}$ by Belovo ${ }^{\circledR}$, eggs enriched in omega-3 and vitamin E, currently exported all over the world and whose annual production is estimated to be over 50 million [22].

In EU, the market of non-alcoholic beverages enriched with vitamins (especially $\mathrm{A}, \mathrm{C}$ and $\mathrm{E}$ ), and other bioactive components, is still running at a modest scale. However, its growth is rising exponentially 
bringing to market various highly appreciated products. In particular, drinks with soy and omega-3 (to lower cholesterol), drinks with lutein (to improve vision) and drinks with calcium and insulin (to improve health issues), can be cited as examples [59]. Germany is a successful representative of this food category mainly due to the success of $\mathrm{ACE}^{\circledR}$ drinks, with a sales income of many millions of dollars in the last decade [22]. Another example of success, especially for its great contribution to the Estonian economy, is the Largo ${ }^{\circledR}$ beverages (juices fortified with inulin, L-carnitine, vitamins, calcium and magnesium) [60]. Also functional liquid dairy products, including yogurts, are among the most succeeding products. These foods are usually enriched with pre- and/or probiotics in order to impart some beneficial functions in the body. This type of dairy products features an impressive growth of many millions of dollars throughout EU. In this area the most representative brands are Danone ${ }^{\circledR}$ and Unilever ${ }^{\mathbb{R}}$, which have faced an exponential growth [22]. A widely known product is Benecol ${ }^{\circledR}$ a dairy beverage enriched with camelina oil as a source of fatty acids, in particular of the omega-3 type associated with cholesterol lowering. Functional butters are another example of products with great market expansion. Becel ${ }^{\circledR}$ pro activ, trade name owned by Becel $^{\circledR}$ (Unilever ${ }^{\circledR}$ ), is a well-known product to lower cholesterol, property related with the added plant stanol esters [61].

Several companies recognized worldwide, betting much of their investment in products referred as "healthier". Food companies such as Nestlé ${ }^{\circledR}$, Danone ${ }^{\circledR}$ Group, Kraft Foods ${ }^{\circledR}$, Unilever $^{\circledR}$, PepsiCo $^{\circledR}$, Coca$\mathrm{Cola}^{\circledR}$, and Heinz ${ }^{\circledR}$ are some of these examples. Recently, there has been also the promotion of some joint-ventures between food industries and pharmaceutical companies, because the cost and time of producing functional foods is lower than producing pharmaceutical products.22

Among all the functional food markets, the major product launches are: milk products, confectionery, bakery and baby foods. ${ }^{19,40}$ The market of functional dairy products has grown rapidly due to the recognized large investment in research directed to the sector, which assured the development of new marketable products. Furthermore, many authors explain the great success of functional dairy products due to the good image consumers have of them $[22,62]$.

\section{PHENOLIC COMPOUNDS AS BIOACTIVE INGREDIENTS}

\subsection{Chemical and biological issues}

The PC are secondary metabolites of plants generally involved in the defense against ultraviolet radiation or aggression by pathogens [63], being the major antioxidants of our diet [64].

Their main dietary sources are fruits and plant-derived beverages such as fruit juices, tea, coffee and red wine. Vegetables, cereals, chocolate, and dry leguminous also contribute to the total PC intake $[65,66]$. The total dietary intake is about $1 \mathrm{~g} /$ day, being much higher than that of all other known dietary antioxidants, about 10 fold higher than that of vitamin $\mathrm{C}$ and 100 fold higher than those of vitamin $\mathrm{E}$ and carotenoids $[64,67]$.

In nature, PC are usually found conjugated to sugars and organic acids [66,68]. They can be classified according to two major types, flavonoids and non-flavonoids (Figure 2) and in different classes, 
which depend on the number of phenol rings and on the structural elements linking these rings $[68,69]$. Nevertheless, there is still some controversy in associated to the classes of PC to be considered [70].

Flavonoid group, shares a common structural feature, consisting of 2 aromatic rings (A and B) bounded together by 3 carbon atoms that form an oxygenated heterocycle (ring $\mathrm{C}$ ). It can be divided into six subclasses according to the type of involved heterocycle: flavonols, flavones, flavanols, flavanones, isoflavones and anthocyanins [69]. The individual differences within each group refer to variations in the number and arrangement of the hydroxyl groups, as well as in their extent of alkylation and/or glycosylation [66]. Among the various compounds, quercetin and catechins stand out as the most common ones.

Several studies have suggested that flavanols, flavones, and flavanones, the main flavonoids found in citrus fruits, occur at high concentration in the cocoa-rich products and dark chocolates, and are related to the reduction of cardiovascular disease risk [71,72].

The non-flavonoids group is composed byphenolic acids, stilbenes and lignans [69]. Phenolic acids are found abundantly in foods and can be divided into two classes: hydroxybenzoic and hydroxycinnamic acids. The hydroxybenzoic acid content in edible plants is generally low, with the exception of certain red fruits and onions. Normally these fruits have large amounts of gallic acid. The hydroxycinnamic acids are more common than hydroxybenzoic acids and consist mainly of coumaric, caffeic, ferulic and rosmarinic acids $[66,69]$. Stilbenes are not typically ingested in large quantities since plants only synthesized them if subjected to episodes of infection or injury. However, grapes and wine contain significant amounts of resveratrol, making this stilbene one of the most studied ones [56]. Lignans, such as secoisolariciresinol, are considered to be phytoestrogens. Its richest dietary source is linseed, which contains secoisolariciresinol and low quantities of matairesinol [59].

Several studies have reported the antioxidant potential of certain PC being apigenin, quercetin, kaempferol, myricetin, luteolin, isorhamnetin, caffeic and $p$-coumaric acids the most cited (Table 1) $[73,74]$. Yeh \& Yen [75] demonstrated that administration of phenolic acids, mainly gallic acid, in rats induces phase II hepatic phenol sulfotransferases (PSTs) and increase plasma antioxidant capacity. Another study administrated an anthocyanin rich extract, obtained from the cones of Abies koreana E.H.Wilson, to male rats and proved that it increased plasma antioxidant capacity [76]. Flavan-3-ols, mostly catechins, were detected in high amounts in rat blood, and were able to suppress the occurrence of gastric lesions in rats [77]. These compounds showed high antioxidant activity leading to a great protection of endothelial cells from oxidative injury [78]. Several studies were conducted to prove the antioxidant properties of flavones. The apigenin revealed strongly antioxidant activity in vitro and in vivo assays through neuroprotective effects against oxidative stress [79,80]. Another flavone, kaempferol, also revealed high antioxidant activity, being recommended as a good natural antioxidant due to its tendency to donate electrons and, therefore, stabilizing food products [81].

The most studied PC in terms of antifungal properties are phenolic acids, flavonoids and stilbenes [6] presented in Table 2. The antimicrobial activity of phenolic acids was reported by various authors which proved that clorogenic, ferulic and gallic acids have the ability to inhibit the growth of different microorganisms such as Staphylococcus aureus and S. epidermis, Escherichia coli, Pseudomonas aeruginosa and Listeria monocytogenes [82-87]. The catechin, belonging to flavan-3-ols group, inhibited 
the growth of various fungi and bacteria strains, such as Candida albicans [88], Helicobacter pylori [86] and Escherichia coli [87]. Also the flavanones, hespertin and narigenin, showed strong antifungal and antibacterial effects against S. aureus, C. albicans and Lactococcus lactis [89-91]. Strong activity against P. aeruginosa, Salmonella typhimurium, S. epidermis, Bacillus subtilis and Saccharomyces cerevisiae was displayed by two examples of flavones, apigenin and luteolin [92,93]. Studies with flavonols (kaempferol and rutin) revealed their antibacterial activity against Enterococcus faecalis and S. aereus [94,95]. The antibacterial activity of genistein, an isoflavone, was studied against Vibrio harveyi [96], Bacillus anthracis [97], Klebsiella pneumonia and Salmonella typhi [98]. Finally, resveratrol, a stilbene, showed antibacterial activity against various bacteria such as E. faecalis [94], Campylobacter spp., Arcobacter butzleri [99], S. cerevisiae, Aspergillus ninger, Penicillum expansum [100] and H. pylori [101], as also against $C$. albicans fungi [102].

Other studies demonstrated that PC possess anti-inflammatory activity (Table 3). Wang et al [103] reported the anti-inflammatory activity of hesperetin, a flavanone, and suggested that this PC was inhibitor of tumor necrosis factor $\alpha$ and interleukin-6 in mouse macrophages. This activity was also verified by different authors for two important flavones, apigenin and luteolin. Funakoshi-Tago et al [104] demonstrated that apigenin effectively inhibited carrageenan-induced inflammation in murine model through inhibition NF- $\mathrm{kB}$ transcriptional activation mechanism. Luteolin was described as having the ability to inhibit tumor necrosis factor $\alpha$ and NF-kB transcriptional activation under in vivo assays $[104,105]$, to reduce nitric oxide synthase expression in vitro [106] and significantly alleviated neurological deficit in vivo suppressed edema after ischemic stroke due the decreased expression of several molecules involved in inflammatory processes [107]. The potent anti-inflammatory effect of luteolin was also described, by interfering essentially in the heat shock protein 90 (Hsp90) secretion [108].

Table 4 represents some PC with proved antitumoral activity. Some authors have shown an inhibition of reductase activity in tumor cells by treating leukemic cell lines with gallic acid [109]. Another study also demonstrated the efficiency of this acid against glioma cell lines, by decreasing cell viability, proliferation and angiogenesis [110]. Other authors reported that by inducing apoptosis and activating caspases, the gallic acid also had efficient effects on lung cancer cell lines. In a study with murine models it was demonstrated the same capability of reducing tumor growth [111]. Some authors demonstrated the anticancer effect of the anthocyanidins, cyaniding and delphinidin, against colorectal carcinoma [112]. In particular, delphinidin inhibited cell growth and decreased tumor size [113]. In vivo assays revealed that catechin, a flavan-3-ol, inhibited tumor formation and increased the life span of the animals. In turn, in vitro tests have confirmed that this compound inhibited the migration of melanoma cells [114]. In a study conducted by Alshatwi [115] catechins proved to exhibit anticancer effects and induce apoptosis on the MCF-7 cancer cell line (breast cancer) without significant toxicity. Within the flavanone group, hespertin could inhibit the cell growth and induce apoptosis resulting on inhibition of human mammary carcinoma cell lines [116]. Alshatwi et al [117] revealed that hespertin exhibited in vitro anticancer activity against human cervical cancer cell lines through the reduction of cell viability and induction of apoptosis. Narigenin proved anti-proliferative and apoptotic effects trough 3-(4,5dimethylthia-zol-2-yl)-2,5-diphenyltetrazolium brumide (MTT) assay in skin carcinoma cells line (A431) 
by inducing ROS generation and cell cycle arrest [118]. In flavone group, apigenin and luteolin are the most studied PC. The apigenin showed anti-mutagenic and apoptotic effects in human lymphoma cells line [119] and inhibited pancreatic cancer cell growth and migration [120]. On the other hand, luteolin exhibited pro-apoptotic activities in colorectal cancer cells [121] and demonstrated anticancer effect on human lung carcinoma cell line (NCI-H460) through Sirt1-mediated apoptosis and the inhibition of cell migration [122]. The luteolin also could synergize the antitumor effects of 5-fluorouracil on HepG2 and Bel7402 cells, which might be related with apoptosis and regulation of 5-fluorouracil metabolism [123]. Moreover, Chian et al [124] demonstrated in vivo that luteolin inhibited nuclear factor (erythroid-derived 2)-like 2 (Nrf2) in mouse liver and significantly enhanced the therapeutic effect of cisplatin both in animal and in cell lines. The luteolin was able to significantly inhibit cellular growth, cell migration, and induce $\mathrm{S}$ and G2/M cell cycle arrest and apoptotic cell death in gioblastoma multiforme (GBM 8401) cells [125], and to attenuate the growth of estrogen receptor in human breast cancer cells (MDA-MB-231) both in vitro and in vivo assays suppressing the proliferation of breast cancer cells in mouse model [126]. Additionally, Yang et al [127] combined luteolin and paclitaxel, which led to an enhancement of apoptosis in human breast cancer cells (MDA-MB-231) and to a decrease in orthotropic tumor growth in nude mice. Quercetin and kaempferol are the two most studied flavonols and were investigated in various human and murine cell lines by different authors, with effective results against cells of different carcinoma [128-134]. The effects of genistein, an isoflavonoid, in prostate carcinoma were assessed by using in vitro assays with human cell lines [135] and in vivo models using murine [136]. The results of these studies indicated that genistein was capable to inhibit cell proliferation as well as to upregulate glutathione peroxidase and downregulate apoptosis inhibitor agents. In stilbene group, resveratrol represent the most important PC. This compound presented a direct antitumor activity against many carcinoma types including leukemia, neuroblastoma, pancreatic, breast, prostate and renal carcinoma $[137,138]$.

The hepatoprotective effects of same PC isolated from natural sources are presented in Table 5. Phenolic acids, namely caffeic, chlorogenic and gallic acids, showed hepatoprotective effects through different mechanisms [139-142]. Within flavanones group, hespertin and naringenin emerge with hepatoprotective properties. The hespertin is responsible for combating against $\mathrm{CCL}_{4}$ (carbon tetrachloride)-induced hepatic damage in mice through decrease of various enzymes [143]. The naringenin showed hypoglycemic, vasorelaxant and hepatoprotective properties through decrease of the enzymes involved in liver diseases [144]. Regarding the flavone group, apigenin and luteolin play an important role in hepatoprotective effects. Various authors described this PC as displaying hepatic properties including the decrease of different enzymes harmful to the liver cells as well as ability to inhibit HepG2 cell line (liver carcinoma) [139,145,146]. Isorhamnetin, kaempferol, myricetin and quercetin are some examples of flavonols implicated in hepatoprotective effects. These compounds were able to reduce damaging enzymes such as aspartate transaminase (AST) and alanine transaminase (ALT) $[142,143,147]$. Additionally, Pereira et al [139] described kaempferol as hepatoprotective agent via reducing the growth of HepG2 cell line.

\subsection{In vitro versus in vivo performance}


Several studies conducted in vitro were designed to evaluate the bioactivity of phenolic compounds extracted from different plants. Despite the scientific relevance of these studies, biochemical, physiological or metabolic parameters are not considered $[2,3,148]$. Thus, there has been an exponential increase in the number of in vivo studies using rats, mice and rabbits; however, studies involving humans are still very scarce [149]. Unfortunately, there is a large number of studies on the in vitro properties of different natural matrices that did not advance to in vivo studies. But, after metabolism, the various compounds can be converted to their active forms or otherwise inactivated or attached to biomolecules, which can modify its original purpose [148]. These effects are not considered on the in vitro assays and, therefore, in vivo validation is always required [3].

In spite of recent scientific advances, the bioavailability of PC is not clearly defined since, during ingestion, digestion and absorption these molecules can undergo various biochemical reactions [6, 150]. Therefore, the in vivo effect of PC cannot simply be extrapolated from the in vitro activities. For example, the antioxidant activity of a particular food verified in vitro differs when tested in vivo [151]. Otherwise, some phenolic complexes have low antioxidant activity when studied in vitro, but in vivo may undergo metabolic transformation into simpler compounds, which leads to an increase in plasma antioxidant capacity [152].

Reviewing Figure 3 it is possible to verify that although the in vivo and in vitro studies with PC have started in 1960, the highest impact has been observed since 1990 for in vitro studies, and five years later for in vivo assays. Despite the exponential increased number of studies, in vitro experiments are always higher than in vivo studies. In contrast there is a higher number of patents for in vivo than in vitro assays suggesting a growing interest from the industry towards these outputs.

\subsection{Bioavailability of phenolic compounds as a main factor in bioactivity}

The large amounts of PC consumption through feed is not directly related to improved bioavailability profile [153]. The health benefits from natural PC depend on their absorption and metabolism [154].

In vitro evaluation systems to determine the bioactive potential of PC are based on the surface of organs such as the inner wall of the gastrointestinal tract, but such systems cannot reflect antioxidant in vivo effects [77] because the physico-chemical characteristics (molecular size, base structure, degree of polymerization and/or glycosylation, solubility, interaction with other compounds) are major factors limiting the PC action [153].

The bioavailability is considered a fundamental step to guarantee the bioefficacy of PC, i.e., at nutritional level, the bioavailability is the fraction of a given food that the organism can utilize, and is therefore a matter of nutritional efficacy [155]. So, the bioavailability of the PC can be affected by various factors that may interfere directly in bioavailability or decreasing the PC amounts in food. External factors, food processing, interaction with other compounds and intestinal factors are some examples of those factors [156]. The bioavailability depends on different and complex processes such as liberation, absorption, distribution, metabolism and elimination phases [155], however, the absorption at intestinal level is considered the limiting factor contributing to the bioavailability decrease. Permeability, lipophilicity, uptake and efflux by transporters are some factors that affect the amounts of each compound 
which is absorbed by the mesenteric architecture and sent to the liver tissues through intestinal cells [157].

Phenolic compounds with small-molecular weight, for example, gallic acid and isoflavones are easily absorbed through the gastrointestinal tract [153]. On the contrary, the majority of PC are relatively poorly absorbed (absorption rates between 0.3 and $43 \%$ ) and the circulation in plasma concentrations of their metabolites can be low [155]. For instance, in flavonols group, the quercetin and kaempferol demonstrated various biological in vitro effects [158]. Nevertheless, the use of these flavonols as a health promoting compound has been limited due its poor bioavailability caused by low water solubility, poorly absorption rate and high instability in neutral and alkaline media including different organs such as small intestine, colon, liver and kidney [157,159]. Additionally, in flavones group, the use of apigenin is also very limited because of its instability and poor solubility in the pure form [160].

\section{PHENOLIC COMPOUNDS IN FUNCTIONAL FOODS AND NUTRACEUTICALS}

\subsection{Health claims}

The health claims of food or its constituents are an essential tool when it comes to marketing, that is, consumers are more likely to consume foods when they are sold as "healthy food". However, regulatory identities are necessary to avoid false claims and deception of consumers [161]. There is a large and growing number of studies conducted in order to characterize the bioactivities of different PC with the aim to introduce them in food and add value to foodstuffs. Despite all the interesting results previously mentioned, PC application in food industry has to overcome various laws and rules. In European Union, the utilization of health claims was regulated in 2006 by EFSA. The health claims suggest or imply the relationship between the food or its constituents with health [161].

The regulations of the European Commission are quite restrictive in their use and applicability. Despite the wide variety of PC with promising bioactivities, the only ones authorized with health claims in the Regulation (EU) No 432/2012 are phenolic olive oil. Still, the conditions of the use of this health claim are limited to a minimum concentration of hydroxytyrosol in a certain amount of olive oil (5 $\mathrm{mg}$ of hydroxytyrosol in $20 \mathrm{~g}$ of olive oil). In these conditions, it is possible to claim that olive oil PC contribute to the protection of blood lipids from oxidative stress [162].

\subsection{Presence in foods with reported bioactivity}

PC are currently receiving high attention because of their beneficial health effects, mainly antioxidant [163,164], anti-inflammatory [165,166], antimicrobial [167], cardio-protective [168], cancerpreventive [16] and neuro-protective [169] properties. These compounds assume different forms in the body allowing prevention or treatment of these diseases [170-173]. Therefore, several studies indicate that an increase in the consumption of foods rich in PC can be associated with the prevention of the mentioned diseases $[64,168,171,174]$.

Table 6 includes examples of some foods rich in PC with the respective reported biological effects associated to their antioxidant activity (prevention of cardiovascular disease and cancer). 
The wine, particularly, red wine, is an important source of flavonoids, especially catechins and procyanidins that proved to have a significant protective effect against coronary heart disease (CHD) $[175,176]$. A correlation was also noticed between increasing levels of flavonoids ingestion from fruit and vegetables and the reduction in CHD [177,178]. Catechins and procyanidins have shown, in vitro, to be powerful inhibitors of LDL (Low Density Lipoprotein) oxidation, higher than, for example, $\alpha$-tocopherol [179]. Moreover, it was described that the moderate consumption of wine by humans leads to an increase in the antioxidant capacity of plasma [180]. Other studies have been carried out on the antioxidant activity - through inhibition of copper-catalysed oxidation of human LDL - of a selection of Californian wines. The relative inhibition of LDL oxidation (calculated with respect to the total phenol concentration of each sample) varied from $46 \%$ to $100 \%$ for red wines, and from $3 \%$ to $6 \%$ for white wines [181].

The quercetin, flavonol also presented in the wine, when ingested in large quantities reduces the incidence of lung cancer [182] and ischemic heart disease [176]. Teissedre \& Landrault [175] studied the in vivo effect of gallic acid (originated from red wine) in rats, noticing a reducing mortality rate from CHD. Catechins present in green tea affect lipid metabolism by different pathways and prevent the appearance of atherosclerotic plaque. Its intake decreases the absorption of triglycerides and cholesterol and these findings are in accordance with the fact that it increases fat excretion [183]. Green tea, due to its components, is also appointed to assist in Alzheimer's disease prevention [184].

Sesso, Gaziano, Buring \& Hennekens [185] studied the relationship between tea and coffee consumption and myocardial infarction; in this study it was verified a $44 \%$ reduction of the cardiovascular risk in the individuals drinking more than one cup of tea per day. For the coffee, significant correlation was achieved. All absorbed catechins, procyanidins and metabolites can contribute to increased antioxidant capacity of plasma. Their cardioprotective effects stem from the ability to inhibit lipid peroxidation, chelate redox-active metals and attenuate other processes involving ROS [176].

The major dietary sources of stilbenes include grapes, wine, soy, peanuts, and peanut products [186]. Stilbenes, namely resveratrol, have shown effects in preventing or treating certain diseases such as breast cancer [187,188] and skin tumors [189]. The resveratrol has been shown to inhibit ribonucleotide reductase and other cellular events associated with initiation, promotion and progression of carcinogenesis [189]. The orange juice and grapefruit juice contain high amounts of hesperretin and naringenin and exhibit anti-carcinogenic effects [190]. Tan et al [129] also studied the antiangiogenic potential of quercetin, which demonstrated to inhibited several important steps of angiogenesis including proliferation, migration and tube formation of human microvascular dermal endothelial cells. Another study reported the synergistic effect of grape components in the prevention of diabetes and cardiovascular diseases, and in the promotion of oral health [184].

The biological activities of PC in the human body are mostly attributed to the ability of these compounds to exert antioxidant actions. The main antioxidant activity of the polyphenols consist in potentiate cell detoxification systems, such as the superoxide dismutase, catalase or glutathione peroxidase systems, and inhibit ROS generating enzymes, such as xanthine oxidase and NADPH oxidase (Nicotinamide Adenine Dinucleotide Phosphate-Oxidase) [168]. However, recent studies suggest that the mechanisms by which PC exert their protective action against cardiovascular diseases and cancer, are not simply due to their redox properties, but due to the ability to bind directly to proteins [191]. Such a mode 
of action would induce the inhibition of key enzymes, the modulation of cell receptors or transcription factors, as well as the perturbation of protein aggregates, which can regulate cell functions related to, e.g. growth and proliferation, inflammation, apoptosis, angiogenesis, metastasis, and immune responses, in various ways by affecting signal transduction pathways [168,192-194]. However, there is a great diversity of $\mathrm{PC}$, and the way in which they interact with the proteins depends on the physical chemical properties of both [191].

Summarizing, PC can be considered as good candidates for the prevention and treatment of several diseases. Ongoing studies are particularly devoted to understand all action mechanisms in the body, including bioavailability features.

\subsection{Applications in functional foods and nutraceutical formulations}

Nowadays, some functional foods and nutraceuticals capturing consumer's interest can be found commercially. The scientific community was able to prove the health beneficial effects of this type of products, which the food and pharmaceutical industries have emulated, making viable the production of some novel and original products of high income. The medicinal and aromatic plants play an important role in this area due to their antioxidant, antimicrobial and other beneficial effects in combating certain diseases.

Figure 4 schematizes possible PC intake processes through fortified foods and their effects in the human body. The incorporation of these compounds in food can be performed directly in its free form; however, microencapsulation technique emerged as a very effective and promising strategy to assure bioavailability of these compounds, helping to surpass problems of food processing and ingestion [195]. After ingestion the compounds are absorbed into the bloodstream causing changes in various cellular mechanisms, leading to prevention of various diseases.

There are many articles in the literature that demonstrate the bioactivity of various plants and fruits PC's, studies reporting its application in functional foods or nutraceutical formulations development, is still scarce. Table 7 lists some examples of PC used as nutraceuticals or bioactive compounds in functional foods. Isoflavones of soy were used in dietary supplements to control the menopausal symptoms, while anthocyanins of cranberry were used in nutraceutical capsules for antioxidant purposes. Moreover examples of case studies with incorporation of phenolic extracts into food matrices are also provided in Table 7. Phenolic extracts of pomegranate fruits were incorporated by Robert et al [196] and Pillai et al [197] in yogurt and pasta, respectively, to enhance antioxidant activity. The phenolic extracts of pomegranate were also incorporated by Çam et al [198] into ice cream aiming at enhancing the antioxidant and $\alpha$-glucosidase inhibitory activities. Ezhilarasai et al [199] and Pasrija et al [200] incorporated garcinia and green tea phenolic extracts, respectively, in bread resulting in a new product with increased antioxidant activity. Chouchouli et al [201] and Martins et al [202] used grape seed and blackberry flowers, respectively, to add value and antioxidant activity to functional yogurts. The incorporation of Veronica phenolic extracts caused an increase in the antibacterial activity of a new cream cheese [203]. More recently, Caleja et al [54,55], incorporated phenolic extracts in cottage cheese using fennel and chamomile extracts, reporting a higher antioxidant activity and an extending shelf-life in comparison with the control cottage cheese without extracts. Also in cottage cheese, the same research 
group incorporated mushroom [204] and rosemary extracts [205] to improve antioxidant properties. Fennel and chamomile extracts were also incorporated in yogurts and showed best results when compared with control and yogurts with a synthetic additive (potassium sorbate - E202) [206].Another recent study described the incorporation of PC of guava flower in bread melanoidins, which retained its quality while adding antioxidant value [207]. Finnaly, Miceli et al [208] showed that the incorporation of borage in fresh pasta introduced antimicrobial properties.

\subsection{Present market and future tendency}

The Compal company (Sumol+Compal, S.A.) has developed products defined as functional and marketed in the form of nectar, as is the case of Compal Vital AntiOx ${ }^{\circledR}$, ensuring antioxidant properties due to the presence of a selected range of red fruits (http://www.compal.pt/\#/pomar/nectares/vital/). Guimarães et al [209] proved that the red fruits are rich in phenolics providing antioxidant activity. However, when added to food, the PC are not present in its pure form, they are added mainly as rich extracts or fruits pulps.

In the field of nutraceuticals and dietary supplements, it is also observed a growing interest enforced by the increase of published works on the topic. In literature, it is common to find the description of product formulations incorporating PC, but through the use of natural extracts typically used to fortify foods. These products have been commonly launched on the market, in the form of tablets or syrups, claiming health benefits due to the presence of PC [210].

Magiera et al [211] reported the presence of fourteen flavonoids in a dietary supplement (not specified), relating them with the shown antioxidant capacity. In another study, performed by Pereira et al. [212], the phenolic profile of different formulations of dietary supplements (infusions, syrups and tablets) based on Cochlospermum angolensis Welw, also known as borututu, used for the treatment and prevention of liver diseases, was described. The amount of PC was also related with the observed antimicrobial activity of the supplements. A similar study was conducted by Bresciani et al [213] in which the authors performed the phenolic characterization of three herbal supplements, through identification by MSn-UHPLC.

Even the development of functional foods and nutraceuticals is considered a fast process, these products often require sound scientific evidence before being introduced in the market. Clinical studies are generally very expensive and thus not affordable for most of the companies dealing with the manufacture this type of food products, which cannot bear the expenses to carry out all tests $[51,184,214]$. For each clinical study, research companies and/or universities need to combine hundreds to thousands of subjects. On average each of these studies can cost several thousands of dollars [41].

Despite the fact that laws related to this type of products are quite different among countries, the labeling rules are similar. It is through labeling that consumers have access to all information concerning food composition and respective health benefits, which in the case of functional foods and nutraceuticals becomes very important [184]. Some studies indicate that women are more influenced to buy new products [215], partly because they are more concerned with health issues [39] but also since they are generally in charge of home shopping. 
The main factors influencing functional foods purchasing are: lifestyle, health awareness, taste for healthier foods [216] and packaging design. So, it is important that consumers have knowledge and familiarity with functional foods [39], product safety [39,217] and information concerning the base product (food matrix) [39,218]. Moreover, legislation changes in the EU panorama in what concerns new products has also helped consumer attitude modification. In that context a greater reliance on the information passed by the labels and advertising regarding nutritional and health virtues of these food products is evident [39].

In general, the functional products still need to overcome some obstacles to ensure success in the market and win consumer confidence. Therefore, to support the high demand for functional foods it is necessary to combine efforts of various areas such as science, industry, market, media, education and governmental policies, and thus manage to develop a reputable product image. The product promotion should be perceived by all age groups, from the youngest to the elderly, and thus must be carried out simply and clearly with accessible vocabulary [184,219]. However, the success the functional foods also depends on the organoleptic attributes, especially flavor, appearance, price and health claims [31]. Therefore, the food industry has to take into consideration some factors for the development/restructuring of functional foods, highlighting: sensory acceptance, price, stability, chemical and functional properties $[41,220]$.

Technological development also allows greater innovation in food products. According with Betoret et al [41], the technologies applied to foods can be divided into three groups. The first group is formed by traditional technologies in food processing. The second group encompasses techniques used to protect biologically active compounds, such as microencapsulation, and the development of edible films, coatings and vacuum impregnation. The third group is made up of the latest technologies that can be applied to develop customized functional products.

PC derived from natural sources are known to exhibit various bioactivities [168], and thus their introduction into food matrices will provide a higher intake. However, the PC can exhibit several instabilities when introduced in foods, arising either from food processing (manufacturing temperatures) or long storage periods in contact with the food matrix, among other factors [41,195]. Thus, technologies progress has introduced advances in the food industry, enabling innovation into food products development. In this context, microencapsulation is one of most frequently applied methods to overcome problems related to PC instability and assure controlled release in foods [221,222].

Microencapsulation is emerging as a technique capable of protecting bioactive compounds, such as phenolics, by means of a protective material (e.g. natural polymer or waxes). Some authors state that with this technique it is possible to protect compounds from adverse conditions such as light, oxidation, hydrolysis and moisture contact, thereby ensuring functionality maintenance and thus bioavailability [195,223-225]. When the bioactive is added to the food matrix in the form of microparticles it is possible to minimize problems related to food storage time (reduce compounds degradation) and prevent deleterious interactions with the food matrix [41,202]. However, it is desired that the introduced microparticles do not alter food texture and flavor [41].

\section{CONCLUSIONS}


Throughout of this review, the biological effects of polyphenols, their action when incorporated into a foodstuff or nutraceutical formulation, as well as their relevance to human health were evidenced. It was shown how PC consumption provides significant protection against disease development and progression, including in cardiovascular and cancer diseases. Despite the existing literature evidences reporting that polyphenols represent a great hope in the prevention of many chronic human diseases, there are still in our opinion fields to explore, particularly in what concerns the elucidation of some action mechanisms.

The demand for functional foods in EU varies considerably from country to country due mainly to tradition and cultural heritages. In terms of marketing, functional foods must be promoted in a clear and objective manner so they can be easily recognized by final consumers. The market should promote clearly the product avoiding excessive scientific vocabulary. The labels should contain a specific logo for these foods ensuring an easy recognition and differentiation from other products.

\section{CONFLICT OF INTEREST}

The authors declare no conflict of interest.

\section{ACKNOWLEDGMENTS}

The authors thank the Foundation for Science and Technology (FCT, Portugal) and FEDER under Programme PT2020 for financial support to CIMO (UID/AGR/00690/2013) and C. Caleja PhD grant (SFRH/BD/93007/2013). To POCI-01-0145-FEDER-006984 (LA LSRE-LCM), funded by FEDER, through POCI-COMPETE2020 and FCT.

\section{REFERENCES}

[1] Branen AL, Davidson PM, Salminen S, Thorngate J. Food additives. Taylor \& Francis, New York, 2001.

[2] Dai J, Mumper RJ. Plant phenolics: extraction, analysis and their antioxidant and anticancer properties. Molecules 2010; 15: 7313-7352.

[3] Rubió L, Motilva M-J, Romero M-P. Recent advances in biologically active compounds in herbs and spices: a review of the most effective antioxidant and anti-inflammatory active principles. CRC Cr Rev Food Sci 2013; 53: 943-953.

[4] Carocho M, Ferreira ICFR. A review on antioxidants, prooxidants and related controversy: natural and synthetic compounds, screening and analysis methodologies and future perspectives. Food Chem Toxicol 2013; 51: 15-25.

[5] Cai YZ, Sun M, Xing J, Luo Q, Corke H. Structure-radical scavenging activity relationships of phenolic compounds from traditional Chinese medicinal plants. Life Sci 2006; 78: 2872-2888.

[6] Martins N, Barros L, Henriques M, Silva S, Ferreira ICFR. Activity of phenolic compounds from plant origin against Candida species. Ind Crop Prod 2015; 74: 648-670. 
[7] Beuchat L. Microbial Food Contamination. CRC Press, London, 2001.

[8] Vulcano I, Halabalaki M, Skaltsounis L, Ganzera M. Quantitative analyses of pungent and antiinflammatory phenolic compounds in olive oil by capillary electrophoresis. Food Chem 2015; 169: 381-386.

[9] Mizgier P, Kucharska A, Sokół- Łętowska A, Kolniak-Ostek J, Kidoń M, Fecka I. Characterization of phenolic compounds and antioxidant and anti-inflammatory properties of red cabbage and purple carrot extracts. J Func Foods 2016; 21: 133-146.

[10] Bowen-Forbes CS, Zhang Y, Nair MG. Anthocyanin content, antioxidant, anti-inflammatory and anticancer properties of blackberry and raspberry fruits. J Food Compost Anal 2010; 23: 554560.

[11] Jemal A, Bray F, Center MM, Ferlay J, Ward E, Forman D. Global cancer statistics, CA. Cancer J Clin 2011; 61: 69-90.

[12] Foo J, Michor F. Evolution of resistance to anti-cancer therapy during general dosing schedules. J Theor Biol 2010; 263: 179- 188.

[13] Rocha AB, Lopes RM, Schwartsman G. Natural products in anticancer therapy. Curr Opin Pharmacol 2001; 1: 364-369.

[14] Gordaliza M. Natural products as leads to anticancer drugs. Clin Trans Oncol 2007; 9: 767-776.

[15] Carocho M, Ferreira ICFR. The Role of Phenolic Compounds in the Fight against Cancer - A Review. Anti-Cancer Agents Med Chem 2013; 13: 1236-1258.

[16] Huang WY, Cai YZ, Zhang Y. Natural phenolic compounds from medicinal herbs and dietary plants: potential use for cancer prevention. Nutr Cancer 2010; 62: 1-20.

[17] Rice CA, Miller NJ, Paganga G. Structure-antioxidant activity relationships of flavonoids and phenolic acids. Free Radical Bio Med 1996; 20: 933-956.

[18] Hardy G. Nutraceutical and functional foods: introduction and meaning. Nutrition 2000; 16: 688698.

[19] Bigliardi B, Galati F. The case of functional foods. Trends Food Sci Tec 2013; 31: 118-129.

[20] Diplock AT, Aggett PJ, Ashwell M, Bornet F, Fern EB, Roberfroid MB. Scientific concepts of functional foods in Europe consensus document. British J Nutr 1999; 81: 1-27.

[21] Spence JT. Challenges related to the composition of functional foods. J Food Compos Anal 2006; 19: S4-S6.

[22] Siró I, Kápolna E, Kápolna B, Lugasi A. Functional food, Product development, marketing and consumer acceptance - A review. Appetite 2008; 51: 456-467.

[23] Hasler CM. Functional foods: Benefits, concerns and challenges - A position paper from the American Council on Science and Health. J Nutr 2002; 132: 3772-3781.

[24] Annunziata A, Vecchio R. Functional foods development in the European market: A consumer perspective. J Func Foods, 2011; 3: 223-228.

[25] Kanekanian A., The Health Benefits of Bioactive Compounds from Milk and Dairy Products in Milk and Dairy Products as Functional Foods, First Edition. Edited by John Wiley \& Sons, Ltd. United Kingdom, 2014.

[26] Hasler CM. The changing face of functional foods. J Am Coll Nutr 2000; 19: 499-506. 
[27] Espín JC, García-Conesa M, Tomás-Barberán F. Nutraceuticals: Facts and fiction. Phytochemistry 2007; 68: 2986-3008.

[28] Braithwaite MC, Tyagi C, Tomar L.K, Kumar P, Choonara YE, Pillay V. Nutraceutical-based therapeutics and formulation strategies augmenting their efficiency to complement modern medicine: An overview. J Func Foods, 2014; 6: 82-99.

[29] Scicchitano P, Cameli M, Maiello M, Modesti PA, Muiesan ML, Novo S, Palmiero P, Saba PS, Pedrinelli R, Ciccone MM. Nutraceuticals and dyslipidaemia: Beyond the common therapeutics. J Func Foods 2014; 6: 11-32.

[30] Carocho M, Barreiro M, Morales P, Ferreira ICFR. Adding Molecules to Food, Pros and Cons: A Review on Synthetic and Natural Food Additives. Comp Rev Food Sci Food Saf 2014; 13: 377 399.

[31] Routray W, Orsat V. Microwave-assisted extraction of flavonoids: a review. Food Bioproc Tech 2012; 5: 409-424.

[32] Chen L, Remondetto GE, Subirade M. Food protein-based materials as nutraceutical delivery systems. Trends Food Sci Tech 2006; 17: 272-283.

[33] McClements DJ, Decker EA, Park Y, Weiss J. Structural design principles for delivery of bioactive components in nutraceuticals and functional foods. Crit. Rev Food Sci 2009; 49: 577-606.

[34] Gulati OP, Ottaway PB. Legislation relating to nutraceuticals in the European Union with a particular focus on botanical-sourced products. Toxicology 2006; 221: 75-87.

[35] Aryee ANA, Boye JI. Nutraceuticals and functional food processing technology, Wiley Blackweel, United Kingdom, 2015.

[36] Wong AY, Lai JMC, Chan AW. Regulations and protection for functional food products in the United States. J Func Foods 2015; 17: 540-551.

[37] Coppens P, Silva MF, Pettman S. European regulations on nutraceuticals, dietary supplements and functional foods: A framework based on safety. Toxicology 2006; 221: 59-74.

[38] Milner JA. Functional foods: The US perspective. Am J Clin Nutr 2000; 71: 1654-1659.

[39] Annunziata A, Vecchio R. Italian Consumer Attitudes Toward Products for Well-being: The Functional Foods Market. Int Food Agribusiness Manag Rev 2010; 13: 19-50.

[40] Menrad K. Market and marketing of functional food in Europe. J Food Eng 2003; 56: 181-188.

[41] Betoret E, Betoret N, Vidal D, Fito P. Functional foods development: Trends and technologies. Trends Food Sci Tec 2011; 22: 498-508.

[42] Verbeke W. Consumer acceptance of functional foods: Sociodemographic, cognitive and attitudinal determinants. Food Qual Prefer 2005; 16: 45-57.

[43] Khan RS, Grigor J, Winger R, Win A. Functional food product development - Opportunities and challenges for food manufacturers. Trends Food Sci Tec 2013; 30: 27-37.

[44] Hilliam M. Fortified juice trends. World Food Ingr 2000; 12: 17-19.

[45] Makinen-Aakula M. Trends in functional foods dairy market. In Proceedings of the third functional food net meeting, 2006.

[46] Monar J.The Spanish functional food market: Present and future perspectives. Functional Food Net (FFNet) network meeting, IATA-CSIC, 2007. 
[47] van Trijp H. Consumer understanding and nutritional communication. In International developments in science \& health claims, ILSI international symposium on functional foods in Europe, 2007.

[48] Ouwehand A. Success in applying pro- and prebiotics in dairy products. In Proceedings of the fourth international FFNet meeting on functional foods, 2007.

[49] Arvanitoyannis JS, Houwelingen-Koukaliaroglou MV. Functional Foods: A Survey of Health Claims, Pros and Cons, and Current Legislation. Crit Rev Food Sci 2005; 45: 385-404.

[50] Institute of Food Technologies, Functional foods: Opportunities and challenges. IFT expert panel report. Retrieved December 2, 2012.

[51] Roy R. Clinical Trial Barriers in Functional Foods and Nutrition in Clinical Aspects of Functional Foods and Nutraceuticals. Edited by Ghosh D., Bagchi, D. and Konishi T., Taylor \& Francis Group, New York, 2015.

[52] Milaneschi Y, Shardell M, Corsi AM, Vazzana R, Bandinelli S, Guralnik JM, Ferrucci L. Serum 25-hydroxyvitamin D and depressive symptoms in older women and men. J Clin Endocr Metab 2010; 95: 3225-3233.

[53] Carocho M, Morales P, Ferreira ICFR. Natural food additives: Quo vadis? Trends Food Sci Tec 2015, doi: 10.1016/j.tifs.2015.06.007

[54] Caleja C, Barros L, António AL, Ciric A, Barreira JCM, Soković M, Oliveira MBPP, SantosBuelga C, Ferreira ICFR. Development of a functional dairy food: exploring bioactive and preservation effects of chamomile (Matricaria recutita L.). J Func Foods 2015; 16: 114-124.

[55] Caleja C, Barros L, António AL, Ciric A, Soković M, Oliveira MBPP, Santos-Buelga C, Ferreira ICFR. Foeniculum vulgare Mill. as natural conservation enhancer and health promoter by incorporation in cottage cheese. J Func Foods 2015; 12: 428-438.

[56] Aun M, Mafra C, Philippi J, Kalil J, Agondi R, Motta A. Aditivos em alimentos. Rev Bras Alerg Imunopatol 2011; 5: 177-186.

[57] Brennan C S, Cleary LJ, The potential use of cereal $(1 \rightarrow 3,1 \rightarrow 4)$-b-Dglucans as functional food ingredients. J Cereal Sci 2005; 42: 1-13.

[58] Benkouider C. The world's emerging markets. Funct Food Nutraceut 2005; 44: 8-11.

[59] Keller C. Trends in beverages and "Measurable Health". In Proceedings of the third functional food net meeting, 2006.

[60] Tammsaar E. Estonian/Baltic functional food market. In Proceedings of the fourth international FFNet meeting on functional foods, 2007.

[61] Hopia A. BENECOL (and Camelina) - Double benefit for heart. In Proceedings of the third functional food net meeting, 2006.

[62] Szakály Z, Szigeti O, Máthé A, Szente V, Nutrimarketing in the service of functional foods. International developments in science \& health claims, ILSI international symposium on functional foods in Europe, 2007.

[63] Crozier A, Clifford MN, Ashihara H. Plant secondary metabolites: occurrence, structure and role in the human diet, Blackwell Publishing, Oxford, 2006.

[64] Scalbert A, Manach C, Morand C, Rémésy C, Jiménez L. Dietary Polyphenols and the Prevention of Diseases. Crit Rev Food Sci 2005; 45: 287-306. 
[65] Scalbert A, Johnson IT, Saltmarsh M. Polyphenols: antioxidants and beyond. Am J Clin Nutr 2005; 81: 215S-217S.

[66] Pandey KB, Rizvi SI. Plant polyphenols as dietary antioxidants in human health and disease. Oxid Med Cell Longev 2009; 2: 270-278.

[67] Scalbert A, Williamson G. Dietary intake and bioavailability of polyphenols. J Nutr 2000; 130: 2073S-2085S.

[68] Yamagata K, Tagami M, Yamori Y. Dietary polyphenols regulate endothelial function and prevent cardiovascular disease. Nutrition 2015; 31: 28-37.

[69] Manach C, Scalbert A, Morand C, Rémésy C, Jiménez L. Polyphenols: food sources and bioavailability. Am J Clin Nutr 2004: 79: 727-747.

[70] O'Connell J, Fox PF, Significance and applications of phenolic compounds in the production and quality of milk and dairy products: a review. Int Dairy J 2001; 11: 103-120.

[71] Hooper L, Kay C, Abdelhamid A, Kroon PA, Cohn JS, Rimm EB, Cassidy A. Effects of chocolate, cocoa, and flavan-3-ols on cardiovascular health: asystematic review and meta-analysis of randomized trials. Am J Clin Nutr 2012; 95: 740-751.

[72] Shrime MG, Bauer SR, McDonald AC, Chowdhury NH, Coltart CE, Ding EL. Flavonoid-rich cocoa consumption affects multiple cardiovascular risk factors in a meta-analysis of short-term studies. J Nutr 2011; 141: 1982-1988.

[73] Sulaiman SF, Sajak AAB, Ooi KL, Seow EM. Effect of solvents in extracting polyphenols and antioxidants of selected raw vegetables. J Food Comps Anal 2011; 24: 506-515.

[74] Wojdylo A, Oszmianski J, Czemerys R. Antioxidant activity and phenolic compounds in 32 selected herbs. Food Chem 2007; 105: 940-949.

[75] Yeh CT, Yen GC. Modulation of hepatic phase II phenol sulfotransferase and antioxidant status by phenolic acids in rats. J Nutr Biochem 2006; 17: 561-569.

[76] Ramirez-Tortosa C, Cabrita L, Andersen ØM, Gardner PT, Morrice PC, Wood SG, Duthie SJ, Collins AR, Garry GG. Anthocyanin-rich extract decreases indices of lipid peroxidation and DNA damage in vitamin E-depleted rats. Free Radical Bio Med 2001; 31: 1033-1037.

[77] Hamauzu Y, Inno T, Kume C, Irie M, Hiramatsu K. Antioxidant and antiulcerative properties of phenolics from Chinese quince, quince, and apple fruits. J Agr Food Chem 2006; 54: 765-772.

[78] Chung JE, Kurisawa M, Kim Y, Uyama H, Kobayashi S. Amplification of antioxidant activity of catechin by polycondensation with acetaldehyde. Biomacromolecules 2004; 5: 113-118.

[79] Zhao L, Wang J, Wang Y, Fa X. Apigenin attenuates copper-mediated $\beta$-amyloid neurotoxicity through antioxidant, mitochondrion protection and MAPK signal inactivation in an AD cell model. Brain Res 2013; 492: 33-45.

[80] Li P, Jia J, Zhang D, Xie J, Xu X, Wei D. In vitro and in vivo antioxidant activities of a flavonoid isolated from celery (Apium graveolens L. var. dulce). Food Funct 2014; 5: 50-56.

[81] Dar RA, Brahman PK, Khurana N, Wagay JA, Lone ZA, Ganaie MA, Pitre KS. Evaluation of antioxidant activity of crocin, podophyllotoxin and kaempferol by chemical, biochemical and electrochemical assays, 2013, http://dx.doi.org/10.1016/j.arabjc.2013.02.004

[82] Chen W-C, Liou S-S, Tzeng T-F, Lee S-L, Liu I-M. Wound repair and anti-inflammatory potential of Lonicera japonica in excision wound-induced rats. BMC Complementary and Alternative Medicine, 2012, vol. 12, no. 1, article 226. 
[83] Borges A, Ferreira C, Saavedra MJ, Simões M. Antibacterial Activity and Mode of Action of Ferulic and Gallic Acids Against Pathogenic Bacteria. Microb Drug Resist 2013; 19: 256-265.

[84] Chanwitheesuk A, Teerawutgulrag A, Kilburn JD, Rakariyatham N. Antimicrobial gallic acid from Caesalpinia mimosoides Lamk. Food Chem 2007; 100: 1044-1048.

[85] Sarjit A, Wang Y, Dykes GA. Antimicrobial activity of gallic acid against thermophilic Campylobacter is strain specific and associated with a loss of calcium ions. Food Microbiol 2015; 46: 227-233.

[86] Díaz-Gómez R, López-Solís R, Obreque-Slier E, Toledo-Araya H. Comparative antibacterial effect of gallic acid and catechin against Helicobacter pylori. LWT - Food Sci. Technology 2013; 54: 331-335.

[87] Díaz-Gómez R, López-Solís R, Obreque-Slier E, Toledo-Araya H. Combined effect of gallic acid and catechin against Escherichia coli. LWT - Food Sci. Technology 2014; 59: 896-900.

[88] Hirasawa M, Takada K. Multiple effects of green tea catechin on the antifungal activity of antimycotics against Candida albicans. J Antimicrob Chemoth 2003; 53: 225-229.

[89] Golfakhrabadi F, Ardekani MRS, Saeidnia S, Yousefbeyk F, Jamalifar H, Ramezani N, Akbarzadeh T, Khanavi M. Phytochemical analysis, antimicrobial, antioxidant activities and total phenols of Ferulago carduchorum in two vegetative stages (flower and fruit). Pak J Pharm Sci 2016; 29: 623-628.

[90] Mandalari G, Bennett RN, Bisignano G, Trombetta D, Saija A, Faulds CB, Gasson MJ, Narbad A. Antimicrobial activity of flavonoids extracted from bergamot (Citrus bergamia Risso) peel, a byproduct of the essential oil industry. J Appl Microbiol 2007; 103: 2056-2064.

[91] Zhang Y, Wang J-F, Dong J, Wei J-Y, Wang Y-N, Dai X-H, Wang X, Luo M-J, Tan W, Deng X$\mathrm{M}$, Niu X-D. Inhibition of $\alpha$-toxin production by subinhibitory concentrations of naringenin controls Staphylococcus aureus pneumonia. Fitoterapia 2013; 86: 92-99.

[92] Nayaka HB, Londonkar RL, Umesh MK, Tukappa A. Antibacterial Attributes of Apigenin, Isolated from Portulaca oleracea L. International Journal of Bacteriology, 2014, Article ID 175851

[93] Akhavan M, Jahangirib S, Shafaghat A. Studies on the antioxidant and antimicrobial activity and flavonoidderivatives from the fruit of Trigonosciadium brachytaenium (Boiss.) Alava. Ind Crop Prod 2015; 63: 114-118.

[94] Valle P, García-Armesto MR, Arriaga D, González-Donquiles C, Rodríguez-Fernández P, Rúa J. Antimicrobial activity of kaempferol and resveratrol in binary combinations with parabens or propyl gallate against Enterococcus faecalis. Food Control 2016; 61: 213-220.

[95] Orhan DD, özçelik B, özgen S, Ergun F. Antibacterial, antifungal, and antiviral activities of some flavonoids. Microbiol Res 2010; 165: 496-504.

[96] Ulanowska K, Tkaczyk A, Konopa G, Wegrzyn G. Differential antibacterial activity of genistein arising from global inhibition of DNA, RNA and protein synthesis in some bacterial strains. Arch Microbiol 2006; 184: 271-278.

[97] Hong H, Landauer MR, Foriska MA, Ledney GD. Antibacterial activity of the soy isoflavone genistein. J Basic Microbiol 2006; 46: 329-335.

[98] Surendhiran D, Karthiga J, Nirmala S, Sirajunnisa AR. Isolation of genistein from Acalypha fruticosa and studying its antibacterial activity by inhibition of bacterial DNA and protein. J Herbal Med Toxicol 2011; 5: 87-96. 
[99] Duarte A, Alves AC, Ferreira S, Silva F, Domingues FC. Resveratrol inclusion complexes: Antibacterial and anti-biofilm activity against Campylobacter spp. and Arcobacter butzleri. Food Res Int 2015; 77: 244-250.

[100] Filip V, Plocková M, Šmidrkal J, Špićková Z, Melzochb K, Schmidtc Š. Resveratrol and its antioxidant and antimicrobial effectiveness. Food Chemistry 2003; 83: 585-593.

[101] Paulo L, Oleastro M, Gallardo E, Queiroz JA, Domingues F. Anti-Helicobacter pylori and urease inhibitory activities of resveratrol and red wine. Food Res Int 2011; 44: 964-969.

[102] Li X-Z, Wei X, Zhang C-J, Jin X-L, Tang J-J, Fan G-J, Zhou B. Hypohalous acid-mediated halogenation of resveratrol and its role in antioxidant and antimicrobial activities. Food Chem 2012; 135: 1239-1244.

[103] Wang Q, Shi J, Chen C, Huang C, Tang W, Li J. Hesperetin derivatives: synthesis and antiinflammatory activity. Bioorgan Med Chem Lett 2016; 26: 1460-1465.

[104] Funakoshi-Tago M, Nakamura K, Tago K, Mashino T, Kasahara T. Anti-inflammatory activity of structurally related flavonoids, Apigenin, Luteolin and Fisetin. Int Immunopharmacol 2011; 11: $1150-1159$.

[105] Jia Z, Nallasamy P, Liu D, Shah H, Li JZ, Chitrakar R, Si H, McCormick J, Zhu H, Zhen W, Li Y. Luteolin protects against vascular inflammation in mice and TNF-alpha-induced monocyte adhesion to endothelial cells via suppressing $\mathrm{IKB} \alpha / \mathrm{NF}-\kappa \mathrm{B}$ signaling pathway. J Nutr Biochem 2015; 26: 293-302.

[106] Sung J, Lee J. Anti-inflammatory activity of butein and luteolin through suppression of NF kB activation and induction of heme oxygenase-1. J Med Food 2015; 18: 557-564.

[107] Qiao H, Zhang X, Zhu C, Dong L, Wang L, Zhang X, Xing Y, Wang C, Ji Y, Cao X. Luteolin downregulates TLR4, TLR5, NF- $\mathrm{BB}$ and p-p38MAPK expression, upregulates the p-ERK expression, and protects rat brains against focal ischemia. Brain Res 2012; 1448: 71-81.

[108] Chen D, Bi A, Dong X, Jianh Y, Rui B, Liu J, Yin Z, Lou L. Luteolin exhibits anti-inflammatory effects by blocking the activity of heat shock protein 90 in macrophages. Biochem Bioph Res Co 2014; 443: 326-332.

[109] Madlener S, Illmer C, Horvath Z, Saiko P, Losert A, Herbacek I, Grusch M, Elford HL, Krupitza G, Bernhaus A, Fritzer-Szekeres M, Szekeres T. Gallic acid inhibits ribonucleotide reductase and cyclooxygenases in human HL-60 promyelocytic leukemia cells. Cancer Lett 2007; 245: 156-162.

[110] Lu Y, Jiang F, Jiang H, Wu K, Zheng X, Cai Y, Katakowski M, Chopp M, To ST. Gallic acid suppresses cell viability, proliferation, invasion and angiogenesis in human Glioma cells. Eur J Pharmacol 2010; 641: 102-107.

[111] Ji B, Hsu W, Yang J, Hsia T, Lu C, Chiang J, Yang J, Lin C, Lin J, Suen L, Wood WG, Chung J. Gallic acid induces apoptosis via caspase-3 and mitochondrion-dependent pathways in vitro and suppresses lung xenograft tumor growth in vivo. J Agric Food Chem 2009; 57: 7596-7604.

[112] Cvorovic J, Tramer F, Granzotto M, Candussio L, Decorti G, Passamonti S. Oxidative stressbased cytotoxicity of delphinidin and cyanidin in colon cancer cells. Arch Biochem Biophys 2010; 501: 151-157.

[113] Hafeez BB, Siddiqui IA, Asim M, Malik A, Afaq F, Adhami VM, Saleem M, Di M, Mukhtar H. A dietary anthocyanidin delphinidin induces apoptosis of human prostate cancer PC 3 cells in vitro and in vivo: involvement of nuclear factor-KB signaling. Cancer Res 2008; 68: 8564-8572.

[114] Menon LG, Kuttan R, Kuttan G. Anti-metastatic activity of curcumin and catechin. Cancer Lett 1999; 141: 159-165. 
[115] Alshatwi AA. Catechin hydrate suppresses MCF-7 proliferation through TP53/Caspase-mediated apoptosis. J Exp Clin Canc Res 2010; 29: 167-176.

[116] Natarajan N, Thamaraiselvan R, Lingaiah H, Srinivasan P, Periyasamy BM. Effect of flavonone hesperidin on the apoptosis of human mammary carcinoma cell line MCF-7. Biomed Preven Nutr 2011; 1: 207-215.

[117] Alshatwi AA, Ramesh E, Periasamy VS, Subash-Babu P. The apoptotic effect of hesperetin on human cervical cancer cells is mediated through cell cycle arrest, death receptor, and mitochondrial pathways. Fundamental \& Clinical Pharmacology 2013; 27: 581-592.

[118] Ahamad MS, Siddiqui S, Jafri A, Ahmad S, Afzal M, Arshad M. Induction of Apoptosis and Antiproliferative Activity of Naringenin in Human Epidermoid Carcinoma Cell through ROS Generation and Cell Cycle Arrest. 2014. PLoS ONE, 9, e110003.

[119] Hashemi M, Long MN, Entezari M, Nafisi S, Nowroozii H. Anti-mutagenic and pro-apoptotic effects of apigenin on human chronic lymphocytic leukemia cells. Acta Med Iran 2010; 48: 283288.

[120] He J, Ning C, Wang Y, Ma T, Huang H, Ge Y, Liu J, Jiang Y. Natural plant flavonoid apigenin directly disrupts Hsp90/Cdc37 complex and inhibits pancreatic cancer cell growth and migration. J Func Foods 2015; 18: 10-21.

[121] Had LA, Vito CD, Marfia G, Ferraretto A, Tringali C, Viani P, Riboni L. Sphingosine kinase 2 and ceramide transport as key targets of the natural flavonoid luteolin to induce apoptosis in colon cancer cells. 2015. PLoS ONE 10(11), e0143384. doi:10.1371/journal.pone.0143384

[122] Ma L, Peng H, Li K, Zhao R, Li L, Yu Y, Wang X, Han Z. Luteolin exerts an anticancer effect on NCI-H460 human non small cell lung cancer cells through the induction of Sirtl-mediated apoptosis. Mol Med Rep 2015; 12: 4196-4202.

[123] Xu H, Yang T, Liu X, Chen X, Yuan R, Su X, Du G. Luteolin synergizes the antitumor effects of 5-fluorouracil against human hepatocellular carcinoma cells through apoptosis induction and metabolism. Life Sci 2016; 144: 138-147.

[124] Chian S. Thapa R, Chi Z, Wang XJ, Tang X. Luteolin inhibits the Nrf2 signaling pathway and tumor growth in vivo. Biochem Bioph Res Co 2014; 447: 602-608.

[125] Tsai Y, Chen H, Hsu H, Lu K, Liang C, Liliang P, Wang K, Wang H, Wang C, Houng J. Luteolin inhibits proliferation of human glioblastoma cells via induction of cell cycle arrest and apoptosis. J Taiwan Inst Chem Eng 2013; 44: 837-845.

[126] Lee E, Oh S, Sung M. Luteolin exerts anti-tumor activity through the suppression of epidermal growth factor receptor-mediated pathway in MDA-MB-231 ER-negative breast cancer cells. Food and Chemical Toxicology 2012; 50: 4136-4143.

[127] Yang M, Wang C, Chen N, Ho W, Lu F, Tseng T. Luteolin enhances paclitaxel-induced apoptosis in human breast cancer MDA-MB-231 cells by blocking STAT3. Chem -Biol Interact 2014; 213 : 60-68.

[128] Wei Y, Zhao X, Kariya Y, Fukata H, Teshigawara K, Uchida A. Induction of apoptosis by quercetin: involvement of heat shock protein. Cancer Res 1994; 54: 4952-4957.

[129] Tan W, Lin L, Li M, Zhang Y, Tong Y, Xiao D, Ding J. Quercetin, a dietary-derived flavonoid, possesses antiangiogenic potential. Eur J Pharmacol 2003; 459: 255-262.

[130] Nair H, Rao KVK, Aalinkeel R, Mahajan S, Chawda R, Schwartz SA. Inhibition of prostate cancer cell colony formation by the flavonoid quercetin correlates with modulation of specific regulatory genes. Clin Diagn Lab Immunol 2004; 11: 63-69. 
[131] Mylonis I, Lakka A, Tsakalof A, Simos G. The dietary flavonoid kaempferol effectively inhibits HIF-1 activity and hepatoma cancer cell viability under hypoxic conditions. Biochem Biophys Res Commun 2010; 398: 74-78.

[132] Zhang Y, Chen AY, Li M, Chen C, Yao Q. Ginkgo biloba extract kaempferol inhibits cell proliferation and induces apoptosis in pancreatic cancer cells. J Surg Res 2008; 148: 17-23.

[133] Luo H, Rankin GO, Juliano N, Jiang B, Chen YC. Kaempferol inhibits VEGF expression and in vitro angiogenesis through a novel ERK-NFjB-cMyc-p21 pathway. Food Chemistry 2012; 130: $321-328$.

[134] Kim S, Hwang K, Choi K. Treatment with kaempferol suppresses breast cancer cell growth caused by estrogen and triclosan in cellular and xenograft breast cancer models. Journal of Nutritional Biochemistry 2016; 28: 70-82.

[135] Suzuki K, Koike H, Matsui H, Ono Y, Hasumi M, Nakazato H, Okugi H, Sekine Y, Oki K, Ito K, Yamamoto T, Fukabori Y, Kurokawa K, Yamanaka H. Genistein, a soy isoflavone, induces glutathione peroxidase in the human prostate cancer cell lines LNCAP and PC-3. Int J Cancer 2002; 99: 846-852.

[136] Wang J, Eltoum I, Lamartiniere CA. Dietary genistein suppresses chemically induced prostate cancer in Lobund-Wistar rats. Cancer Lett 2002; 186: 11-18.

[137] Simoni D, Roberti M, Invidiata FP, Aiello E, Aiello S, Marchetti P, Baruchello R, Eleopra M, Cristina AD, Grimaudo S, Gebbia N, Crosta L, Dieli F, Tolomeo M. Stilbene-based anticancer agents: resveratrol analogues active toward HL60 leukemic cells with a non-specific phase mechanism. Bioorg Med Chem Lett 2006; 16: 3245-3248.

[138] Fulda S, Debatin K. Sensitization for anticancer drug-induced apoptosis by the chemopreventive agent resveratrol. Oncogene 2004; 23: 6702-6711.

[139] Pereira C, Calhelha RC, Barros L, Ferreira ICFR. Antioxidant properties, anti-hepatocellular carcinoma activity and hepatotoxicity of artichoke, milk thistle and borututu. Ind Crop Prod 2013; 49: 61-65.

[140] Nabavi SF, Nabavi SM, Habtemariam S, Moghaddam AH, Sureda A, Jafari M, Latifi AM. Hepatoprotective effect of gallic acid isolated from Peltiphyllum peltatum against sodium fluoride-induced oxidative stress. Ind Crop Prod 2013; 44: 50-55.

[141] Zhao Y, Geng C-A, Ma Y-B, Huang X-Y, Chen H, Cao T-W, He K, Wang H, Zhang X-M, Chen JJ. UFLC/MS-IT-TOF guided isolation of anti-HBV active chlorogenic acid analogues from Artemisia capillaris as a traditional Chinese herb for the treatment of hepatitis. J Ethnopharmacol 2014; 156: 147-154.

[142] Maheshwari DT, Kumar MSY, Verma SK, Singh VK, Singh SN. Antioxidant and hepatoprotective activities of phenolic rich fraction of sea buckthorn (Hippophae rhamnoides L.) leaves. Food Chem Toxicol 2011; 49: 2422-2428.

[143] Cheng N, Ren N, Gao H, Lei X, Zheng J, Cao W. Antioxidant and hepatoprotective effects of Schisandra chinensis pollen extract on CCl4-induced acute liver damage in mice. Food Chem Toxicol 2013; 55: 234-240.

[144] Sánchez-Salgado JC, Ortiz-Andrade RR, Aguirre-Crespo F, Vergara-Galicia J, Léon-Rivera I, Montes S, Villalobos-Molina R, Estrada-Soto S. Hypoglycemic, vasorelaxant and hepatoprotective effects of Cochlospermum vitifolium (Willd.) Sprengel: a potential agent for the treatment of metabolic syndrome. J Ethnopharmacol 2007; 109: 400-405.

[145] Oh H, Kim D-H, Cho J-H, Kim Y-C. Hepatoprotective and free radical scavenging activities of phenolic petrosins and flavonoids isolated from Equisetum arvense. J Ethnopharmacol 2004; 95: $421-424$ 
[146] Jeyadevi R, Sivasudha T, Rameshkumar A, Harnly JM, Lin L-Z. Phenolic profiling by UPLC$\mathrm{MS} / \mathrm{MS}$ and hepatoprotective activity of Cardiospermum halicacabum against $\mathrm{CCl} 4$ induced liver injury in Wistar rats. J Func Foods 2013; 5: 289-298.

[147] Sintayehu B, Bucar F, Veeresham C, Asres K. Hepatoprotective and free radical scavenging activities of extracts and amajor compound isolated from the leaves of Cineraria abyssinica Sch. Bip. exA. Rich. Pharmacogn J 2012; 4: 40-46.

[148] Martins N, Barros L, Ferreira ICFR. In vivo antioxidant activity of phenolic compounds: Facts and gaps. Trends Food Sci Tech 2016; 48: 1-12.

[149] Martins N, Barros L, Henriques M, Silva S, Ferreira ICFR. In vivo anti-Candida activity of phenolic extracts and compounds: future perspectives focusing on effective clinical interventions. BioMed Res Int 2015, Article ID 247382, 14 pages.

[150] Holst B, Williamson G. Nutrients and phytochemicals: from bioavailability to bioefficacy beyond antioxidants. Curr Opin Biotechnol 2008; 19: 73-82.

[151] Fernandez-Panchon MS, Villano D, Troncoso AM, Garcia-Parrilla MC. Antioxidant activity of phenolic compounds: from in vitro results to in vivo evidence. Crit Rev Food Sci Nutr 2008; 48: 649-671.

[152] Déprez S, Brezillon C, Rabot S, Philippe C, Mila I, Lapierre C, Scalbert A. Polymeric proanthocyanidins are catabolized by human colonic microflora into low molecular-weight phenolic acids. J Nutr 2000; 130: 2733-2738.

[153] Carbonell-Capella JM, Buniowska M, Barba FJ, Esteve MJ, Frígola A. Analytical methods for determining bioavailability and bioaccessibility of bioactive compounds from fruits and vegetables: a review. Compr Rev Food Sci F 2014; 13: 155-171.

[154] Balasundram N, Sundram K, Samman S. Phenolic compounds in plants and agri-industrial byproducts: antioxidant activity, occurrence, and potential uses. Food Chem 2006; 99: 191-203.

[155] Rein M, Renouf M, Cruz-Hernandez C, Actis-Goretta L, Thakkar SK, Pinto MS. Bioavailability of bioactive food compounds: a challenging journey to bioefficacy. Br J Clin Pharmacol 2012; 75: 588-602.

[156] D’Archivio M, Filesi C, Varì R, Scazzocchio B, Masella R. Bioavailability of the polyphenols: Satatus and Controversies. Int J Mol Sci 2010; 11: 1321-1342.

[157] Devi KP, Malar DS, Nabavi SF, Sureda A, Xiao J, Nabavi SM, Daglia M. Kaempferol and inflammation: From chemestry to medicine. Pharmacological research 2015; 99: 1-10.

[158] Kawabata K, Mukai R, Ishisaka A. Quercetin and related polyphenols: new insights and implications for their bioactivity and bioavailability. Food Funct 2015; 6: 1399-1417.

[159] Wang Y, Wang X. Binding, stability, and antioxidant activity of Quercetin with soy protein isolate particles. Food Chem 2015; 188: 24-29.

[160] Xiao Y, Lee I. Microbial metabolism of prenylated apigenin derivatives by Mucor hiemalis. Phytochemistry Letters 2016; 16: 197-202.

[161] Martín-Peláez S, Covas MI, Fitó M, Kusar A, Pravst I. Health effects of olive oil polyphenols: Recent advances and possibilities for the use of health claims. Mol Nutr Food Res 2013; 57: 760771.

[162] Regulamento (UE) N. ${ }^{\circ} 432 / 2012$ da Comissão de 16 de maio de 2012.

[163] Xiao Z, Fang L, Niu Y, Yu H. Effect of cultivar and variety on phenolic compounds and antioxidant activity of cherry wine. Food Chem 2015; 186: 69-73. 
[164] Moussi K, Nayak B, Perkins LB, Dahmoune F, Madani K, Chibane M. M. HPLC-DAD profile of phenolic compounds and antioxidant activity of leaves extract of Rhamnus alaternus L. Ind Crop Prod 2015; 74: 858-866.

[165] García-Lafuente A, Guillamón E, Villares A, Rostagno MA, Martínez JA. Flavonoids as antiinflammatory agents: implications in cancer and cardiovascular disease. Inflam Res 2009; 58: $537-552$

[166] Martin DA, Taheri R, Brand MH, Draghi A, Sylvester FA, Bolling BW. Anti-inflammatory activity of aronia berry extracts in murine splenocytes. J Func Foods 2014; 8: 68-75.

[167] Chakraborty M, Mitra A. The antioxidant and antimicrobial properties of the methanolic extract from Cocos nucifera mesocarp. Food Chem 2008; 107: 994-999.

[168] Quiñones M, Miguel M, Aleixandre A. Beneficial effects of polyphenols on cardiovascular disease. Pharmacol Res 2013; 68: 125-131.

[169] Tavares L, Figueira I, Macedo D, McDougall GJ, Leitão MC, Vieira HLA, Stewart D, Alves PM, Ferreira RB, Santos CN. Neuroprotective effect of blackberry (Rubus sp.) polyphenols is potentiated after simulated gastrointestinal digestion. Food Chem 2012; 131: 1443-1452.

[170] Liu RH. Health benefits of fruit and vegetables are from additive and synergistic combinations of phytochemicals. Am J Clin Nutr 2003; 78: 517S-520S.

[171] Khan N, Mukhtar H. Tea polyphenols for health promotion. Life Sci 2007; 81: 519-533.

[172] Robles-Sánchez M, Astiazarán-García H, Martín-Belloso O, Gorinstein S, Parrilla A-E, Rosa LA, Yepiz-Plascencia G, González-Aguilar GA. Influence of whole and fresh-cut mango intake on plasma lipids and antioxidant capacity of healthy adults. Food Res Int 2011; 44: 1386-1391.

[173] Kishimoto Y, Tani M, Kondo K. Pleiotropic preventive effects of dietary polyphenols in cardiovascular diseases. Eu J Clin Nutr 2013; 67: 532-535.

[174] Perez-Vizcaino F, Duarte J, Jimenez R, Santos-Buelga C, Osuna A. Antihypertensive effects of the flavonoid quercetin. Pharmacol Report 2009; 61: 67-75.

[175] Teissedre PL, Landrault N. Wine phenolics: contribution to dietary intake and bioavailability. Food Res Int 2000; 33: 461-467.

[176] Auger C, Al-Awwadi N, Bornet A, Rouanet J, Gasc F, Cros G, Teissedre P. Catechins and procyanidins in Mediterranean diets. Food Res Int 2004; 37: 233-245.

[177] Hertog M, Hollman PCH, Katan MB, Kromhout D. Intake of potentially anticarcinogenic flavonoids and their determinants in adults in The Netherlands. Nutr Cancer 1993; 20: 21-29.

[178] Rimm EB, Katan MB, Ascherio A, Stampfer MJ. Relation between intake of flavonoids and risk for coronary heart disease in male health professionals. Willett, Ann Intern Med 1996; 155: 391396.

[179] Teissedre PL, Frankel EN, Waterhouse AL, Peleg H, German JB. Inhibition of in vitro human LDL oxidation by phenolic antioxidants from grapes and wines. J Sci Food Agric 1996; 122: $157-168$.

[180] Fuhrman B, Lavy A, Aviram M. Consumption of red wine with meals reduces the susceptibility to human plasma and low density lipoprotein to lipid peroxydation. Am J Clin Nutr 1995; 61: 549554.

[181] Frankel EN, Waterhouse AL, Teissedre PL. Principal phenolic phytochemicals in selected California wines and their antioxidant activity in inhibiting oxidation of human low-density lipoprotein. Journal of Agricultural and Food Chem 1995; 43: 890-894. 
[182] Knekt P, Kumpulainen J, Jarvinen R, Rissanen H, Heliovaara M, Reunanen A, Hakulinen T, Aromaa A Flavonoid intake and risk of chronic diseases. Am J Clin Nutr 2002; 76: 560-568.

[183] Raederstorff DG, Schlachter MF, Elste V, Weber P. Effect of EGCG on lipid absorption and plasma lipid levels in rats. J Nutr Biochem 2003; 14: 326-332.

[184] Wang C, Li S, Functional Foods and Nutraceuticals: Potential Role in Human Health in Clinical Aspects of Functional Foods and Nutraceuticals. Edited by Ghosh D., Bagchi, D. and Konishi T., Taylor \& Francis Group,New York, 2015.

[185] Sesso HD, Gaziano JM, Buring JE, Hennekens CH. Coffee and tea intake and the risk of myocardial infarction. Am J Epidemiol 1999; 149: 162-167.

[186] Cassidy A, Hanley B, Lamuela-Ravento's RM. Isoflavone, lignans and stilbenes-origins, metabolism and potential importance to human health. J Sci Food and Agric 2000; 80: 10441062.

[187] Williams RL, Elliott M, Perry R, Greaves B. The estrogenic activity of the polyphenolic resveratrol, benefits of moderate consumption of red wine. Polyphenols Commun 1996; 96: 489490.

[188] Kris-Etherton PM, Hecker KD, Bonanome A, Coval SM, Binkoski AE, Hilpert KF, Griel AE, Etherton TD. Bioactive Compounds in Foods: Their Role in the Prevention of Cardiovascular Disease and Cancer. Medicine 2002; 113(9B): 71S-88S.

[189] Jang M, Cai L, Udeani GO, Slowing KU, Thomas CF, Beecher CW, Fong HHS, Farnsworth NR, Kinghorn AD, Mehta RG, Moon RC, Pezzuto JM. Cancer chemoprotective activity of resveratrol, a natural product derived from grapes. Science 1997; 275: 218-220.

[190] Erlund I, Meririnne E, Alfthan G, Aro A. Plasma kinetics and urinary excretion of the flavanones naringenin and hesperetin in humans after ingestion of orange juice and grapefruit juice. $\mathrm{J}$ Nutr 2001; 131: 235-241.

[191] Quideau S, Deffieux D, Douat-Casassus C, Pouységu L. Plant polyphenols: chemical properties, biological activities, and synthesis, Angew. Chem. Int. Ed., 2011, 50, 586 - 621.

[192] Gharras HE. Polyphenols: food sources, properties and applications - a review. Int J Food Sci Tech 2009; 44: 2512-2518.

[193] Spencer JPE. The impact of flavonoids on memory: physiological and molecular considerations. Clin Biochem 2009; 38: 1152-1161.

[194] Yang CS, Wang X, Lu G, Picinich SC. Cancer prevention by tea: animal studies, molecular mechanisms and human relevance. Nat Rev Cancer 2009; 9: 429-439.

[195] Dias MI, Ferreira ICFR, Barreiro MF. Microencapsulation of bioactives for food applications. Food Funct 2015; DOI: 10.1039/c4fo01175a.

[196] Robert P, Gorena T, Romero N, Sepulveda E, Chavez J, Saenz C. Encapsulation of polyphenols and anthocyanins from pomegranate (Punica granatum) by spray drying. Int J Food Sci Tech 2010; 45: 1386-1394.

[197] Pillai DS, Prabhasankar B, Jena BS, Anandharamakrishnan C. Microencapsulation of Garcinia Cowa Fruit Extract and Effect of its use on Pasta Process and Quality. Int J Food Proper 2012; 15: 590-604.

[198] Çam M, İçyer NC, Erdoğan F. Pomegranate peel phenolics: Microencapsulation, storage stability and potential ingredient for functional food development. LWT-Food Sci Technol 2014; 55: 117123 
[199] Ezhilarasai P, Indrani D, Jena B, Anandharamakrishnan C. Freeze drying technique for microencapsulation of Garcinia fruit extract and its effect on bread quality. J Food Eng 2013; 117: 513-520.

[200] Pasrija D, Ezhilarasi PN, Indrani D, Anandharamakrishnan C. Microencapsulation of green tea polyphenols and its effect on incorporated bread quality. LWT - Food Sci Technol 2015; 64: 289296.

[201] Chouchouli V, Kalogeropoulos N, Konteles SJ, Karvela E, Makris DP, Karathanos VT. Fortification of yoghurts with grape (Vitis vinifera) seed extracts. LWT - Food Sci Technol 2013; 53: $522-529$.

[202] Martins A, Barros L, Carvalho AM, Santos-Buelga C, Fernandes IP, Barreiro F, Ferreira ICFR. Phenolic extracts of Rubus ulmifolius Schott flowers: characterization, microencapsulation and incorporation into yogurts as nutraceutical sources. Food Funct 2014; 5: 1091-1100.

[203] Stojković DS, Živković J. Soković M, Glamoč J, Ferreira ICFR, Janković T, Maksimović Z. Antibacterial activity of Veronica montana L. extract and of protocatechuic acid incorporated in a food system. Food Chem Toxicol 2013; 55: 209-213.

[204] Ribeiro A, Ruphuy G, Lopes JC, Dias MM, Barros L, Barreiro F, \& Ferreira ICFR. Spray-drying microencapsulation of synergistic antioxidant mushroom extracts and their use as functional food ingredients. Food Chemistry 2015; 188: 612-618.

[205] Ribeiro A, Caleja C, Barros L, Santos-Buelga C, Barreiro MF, Ferreira ICFR. Rosemary extracts in functional foods: extraction, chemical characterization and incorporation of free and microencapsulated forms in cottage cheese. Food \& Function 2016; 7: 2185-2196.

[206] Caleja C, Barros L, Antonio AL, Carocho M, Oliveira MBPP, Ferreira ICFR. Fortification of yogurts with different antioxidant preservatives: a comparative study between natural and synthetic additives. Food Chemistry 2016; 210: 262-268.

[207] Alves G, Perrone D. Breads enriched with guava flour as a tool for studying the incorporation of phenolic compounds in bread melanoidins. Food Chem 2015; 185: 65-74.

[208] Miceli A, Francesca N, Moschetti G, Settanni L. The influence of addition of Borgo officinalis with antibacterial activity on the sensory quality of fresh pasta. International Journal of gastronomy and Food Science 2015; 2: 93-97.

[209] Guimarães R, Barros L, Dueñas M, Carvalho AM, Queiroz MJRP, Santos-Buelga C, Ferreira ICFR. Characterisation of phenolic compounds in wild fruits from Northeastern Portugal. Food Chem 2013; 141: 3721-3730.

[210] Ahmad N, Zuo Y, Lu X, Anwar F, Hameed S. Characterization of free and conjugated phenolic compounds in fruits of selected wild plants. Food Chem 2015; 190: 80-89.

[211] Magiera S, Baranowska I, Lautenszleger A. UHPLC-UV method for the determination of flavonoids in dietarysupplements and for evaluation of their antioxidant activities. J Pharmaceut Biomed Anal 2015; 102: 468-475.

[212] Pereira C, Barros L, Alves MJ, Pereira L, Santos-Buelga C, Ferreira ICFR. Phenolic profile and antimicrobial activity of different dietary supplements based on Cochlospermum angolensis Welw. Ind Crop Prod 2015; 74: 412-416.

[213] Bresciani L, Calani L, Cossu M, Mena P, Sayegh M, Ray S, Rio DD. (Poly)phenolic characterization of three food supplements containing 36 different fruits, vegetables and berries. Pharma Nutr 2015; 3: 11-19.

[214] DiMasi JA, Hansen RW, Grabowski HG. The price of innovation: New estimates of drug development costs. J Health Econ 2003; 22: 151-185. 
[215] Urala N, Lahteenmaki L. Consumers' changing attitudes towards functional foods. Food Qual Prefer 2007; 18: 1-12.

[216] Cox DN, Koster A, Russell CG. Predicting intentions to consume functional foods and supplements to offset memory loss using an adaptation of protection motivation theory. Appetite 2004; 33: 55-64.

[217] Verschuren PM. Functional Foods: Scientific and Global Perspectives. British J Nutr 2002; 88: 126-130.

[218] Rams S. Factors influencing the purchase of functional food products, Bonn: Friedrich-WilhelmsUniversität, 2002.

[219] Azzurra A, Paola P. Consumers' behaviours and attitudes toward healthy food products: The case of Organic and Functional foods. $113^{\text {th }}$ EAAE Seminar "A resilient European food industry and food chain in a challenging world", Greece, 2009.

[220] Granato D, Branco GF, Nazzaro F. Functional foods and nondairy probiotic food development: trends, Concepts and products. Compr Rev Food Sci Food Saf 2010; 9: 292-302.

[221] Fang ZX, Bhandari B. Comparing the efficiency of protein and maltodextrin on spray drying of bayberry juice. Food Res Int 2012; 48: 478-483.

[222] Paini M, Aliakbarian B, Casazza AA, Lagazzo A, Botter R, Perego P. Microencapsulation of phenolic compounds from olive pomace using spray drying: A study of operative parameters. LWT - Food Sci. Technol 2015; 62: 177-182.

[223] Gharsallaoui A, Roudaut G, Chambin O, Voilley A, Saurel R. Applications of spray-drying in microencapsulationof food ingredients: An overview. Food Res Int 2007; 40: 1107-1121.

[224] Fang ZX, Bhandari B. Encapsulation of polyphenols - a review. Trends Food Sci Tec 2010; 21: 510-523.

[225] Aizpurua-Olaizola O, Navarro P, Vallejo A, Olivares M, Etxebarria N, Usobiaga A. Microencapsulation and storage stability of polyphenols from Vitis vinifera grape wastes. Food Chem 2016; 190: 614-621.

[226] Mazza G, Maniati E. Anthocyanins in fruits, vegetables, and grains. CRC Press, United Kingdom, 1993.

[227] Clifford MN. Anthocyanins-nature, occurrence and dietary burden. J Sci Food Agric 2000; 80: 1063-1072.

[228] Hammerstone JF, Lazarus SA, Schmitz HH. Procyanidin Content and Variation in Some Commonly Consumed Foods. J Nutr 2000; 130: 2086S-2092S.

[229] Mangiapane H, Thomson J, Salter A, Brown S, Bell GD, White DA. The inhibition of oxidation of low density lipoprotein by $(+)$-catechin, a naturally occurring flavonoid. Biochem Pharmacol 1992; 43: 445-450.

[230] Lotito SB, Fraga CG. Catechin prevents human plasma oxidation. Free Radical Bio Med 1998; 24 : 435-441.

[231] Pascual-Teresa S, Santos-Buelga C, Rivas-Gonzalo JC. Quantitative analysis of flavan-3-ols in Spanish foodstuffs and beverages. J Agr Food Chem 2000; 48: 5331-5337.

[232] Gu L, Kelm MA, Hammerstone JF, Beecher G, Holden J, Haytowitz D, Gebhardt S, Prior RL. Concentrations of Proanthocyanidins in Common Foods and Estimations of Normal Consumption. J Nutr 2004; 134: 613-617. 
[233] Dwyer JP, Bhagwat S, Haytowitz D, Holden J, Eldridge AL, Beecher G, Aladesanmi J. Major flavonoids in dry tea. J Food Compos Anal 2005; 18: 487-501.

[234] Ding EL, Hutfless SM, Ding X, Girotra S. Chocolate and prevention of cardiovascular disease: a systematic review. Nutr Metab 2006; 3: 2.

[235] Hertog M, Kromhout D, Aravanis C, Blackburn H, Buzina R, Fidanza F, Giampaoli S, Jansen A, Menotti A, Nedeljkovic S, Pekkarinen M, Simic B, Toshima H, Feskens E, Hollman P, Katan M. Flavonoid intake and long term risk of coronary heart disease and cancer in the Seven Countries Study. Arch Intern Med 1995; 155: 381-386.

[236] Crozier A, Lean MEJ, McDonald MS, Black C. Quantitative Analysis of the Flavonoid Content of Commercial Tomatoes, Onions, Lettuce, and Celery. J Agr Food Chem 1997; 45: 590-595.

[237] McDonald MS, Black C. Quantitative analysis of the flavonoid content of commercial tomatoes, onions, lettuce and celery. J Agr Food Chem 1998; 45: 590-595.

[238] Justesen U, Knuthsen P, Leth T. Determination of plant polyphenols in Danish foodstuffs by HPLC-UV and LC-MS detection. Cancer Lett 1997; 114: 165-167.

[239] Aziz A, Edwards CA, Lean MEJ, Crozier A. Absorption and excretion of conjugated flavonols, including quercetin-4-o--glucoside and isorhamnetin-4-o-glucoside by human volunteers after the consumption of onions. Free Radical Res 1998; 29: 257-269.

[240] Anderson JW, Johnstone BM, Cook-Newell ME. Metaanalysis of the effects of soy protein intake on serum lipids. New Engl J Med 1995; 333: 276-282.

[241] Anthony MS, Clarson TB, Hughes CL, Morgan TM, Burke GL. Soybean isoflavones improve cardiovascular risk factors without affecting the reproductive system in prepubertal monkeys. J Nutr 1996; 126: 43-50.

[242] Soleas GJ, Diamandis EP, Goldberg DM. Resveratrol: a molecule whose time has come and gone? Clin Biochem 1997; 30: 91-113.

[243] Sobolev VS, Cole RJ. trans-Resveratrol content in commercial peanuts and peanut products. J Agr Food Chem 1999; 47: 1435-1439.

[244] Sanders TH, McMichael RW, Hendrix KW. Occurrence of resveratrol in edible peanuts. J Agr Food Chem 2000; 48: 1243-1246.

[245] Burns J, Yokota T, Ashihara H, Lean MEJ, Crozier A. Plant Foods and Herbal Sources of Resveratrol. J Agr Food Chem 2002; 50: 3337-3340.

[246] Li W, Friel J, Beta T. An evaluation of the antioxidant properties and aroma quality of infant cereals. Food Chem 2010; 121: 1095-1102.

[247] Bononi M, Tateo F. Stabilization of cranberry anthocyanins in nutraceutical capsules. Int J Food Sci Nutr 2007; 58: 142-149.

[248] Krenn L, Pötsch V. An efficient HPLC method for the quantification of isoflavones in soy extracts and soy dietary supplements in routine quality control. Pharmazie 2006; 61: 582-585.

[249] Barbosa-Pereira L, Angulo I, Lagarón JM, Paseiro-Losada P, Cruz JM. Development of new active packaging films containing bioactive nanocomposites. Innov Food Sci Emerg Technol 2014; 26: 310-318. 
Table 1. Examples of phenolic compounds with antioxidant activity.

\begin{tabular}{|c|c|c|c|c|}
\hline \multicolumn{2}{|c|}{ Phenolic compound } & \multirow{2}{*}{$\begin{array}{l}\text { Effect } \\
\text { Increase of P-Form PST activity }\end{array}$} & \multirow{2}{*}{\multicolumn{2}{|c|}{$\begin{array}{l}\text { Type of } \\
\text { assay } \\
\begin{array}{l}\text { In vivo } \\
\text { (rats) }\end{array}\end{array}$}} \\
\hline $\begin{array}{l}\text { Phenolic } \\
\text { acids }\end{array}$ & Gallic acid & & & \\
\hline Anthocyanins & $\begin{array}{l}\text { Cyanidin; Delphinidin; } \\
\text { Malvidin; Petunidin }\end{array}$ & $\begin{array}{l}\text { Donation of electrons or hydrogen } \\
\text { atoms from hydroxyl moieties to } \\
\text { free radicals }\end{array}$ & $\begin{array}{l}\text { In vivo } \\
\text { (rats) }\end{array}$ & {$[76]$} \\
\hline \multirow[t]{2}{*}{ Flavan-3-ols } & Catechin & $\begin{array}{l}\text { DPPH radical scavenging activity } \\
\text { and linoleic acid peroxidation } \\
\text { inhibition }\end{array}$ & $\begin{array}{l}\text { In vitro } \\
\text { In vivo } \\
\text { (rats) }\end{array}$ & [77] \\
\hline & & $\begin{array}{l}\text { Superoxide radical scavenging } \\
\text { activity and reducing power }\end{array}$ & In vitro & {$[78]$} \\
\hline \multirow[t]{3}{*}{ Flavones } & Apigenin & $\begin{array}{l}\text { Reduction of intracellular reactive } \\
\text { oxygen species }\end{array}$ & In vitro & [79] \\
\hline & & $\begin{array}{l}\text { DPPH radical, superoxide radical } \\
\text { and hydroxyl radical scavenging } \\
\text { activity } \\
\text { Stimulation of antioxidant enzymes } \\
\text { to provide additional protection for } \\
\text { heart, liver and kidney. }\end{array}$ & $\begin{array}{l}\text { In vitro } \\
\text { In vivo } \\
\text { (mice) }\end{array}$ & [80] \\
\hline & Kaempferol & $\begin{array}{l}\text { DPPH radical scavenging activity, } \\
\text { reducing power and lipid } \\
\text { peroxidation inhibition }\end{array}$ & In vitro & [81] \\
\hline
\end{tabular}


Table 2. Examples of phenolic compounds with antimicrobial activity.

\begin{tabular}{|c|c|c|c|c|}
\hline \multicolumn{2}{|c|}{ Phenolic compound } & \multirow{2}{*}{$\begin{array}{l}\text { Bacteria/Fungi } \\
\text { Staphylococcus aureus, Staphylococcus } \\
\text { epidermidis, Escherichia coli, Candida albicans, } \\
\text { and tropicalis (antiwound infection, repair and } \\
\text { contraction) }\end{array}$} & \multirow{2}{*}{$\begin{array}{l}\text { Type of assay } \\
\text { In vitro } \\
\text { In vivo (rodent) }\end{array}$} & \multirow{2}{*}{$\begin{array}{l}\text { Reference } \\
82]\end{array}$} \\
\hline $\begin{array}{l}\text { Phenolic } \\
\text { acids }\end{array}$ & $\begin{array}{l}\text { Chlorogenic } \\
\text { acid }\end{array}$ & & & \\
\hline & Ferulic acid & $\begin{array}{l}\text { Escherichia coli, Pseudomonas aeruginosa, } \\
\text { Staphylococcus aureus, and Listeria } \\
\text { monocytogenes }\end{array}$ & In vitro & {$[83]$} \\
\hline & Gallic acid & $\begin{array}{l}\text { Escherichia coli, Salmonella typhi, Vibrio } \\
\text { cholera, Enterococcus faecalis, Staphylococcus } \\
\text { aureus, Staphylococcus epidermidis; } \\
\text { Microsporum gypseum, Trichophypon rubrum }\end{array}$ & In vitro & {$[84]$} \\
\hline & & $\begin{array}{l}\text { Escherichia coli, Pseudomonas aeruginosa, } \\
\text { Staphylococcus aureus, and Listeria } \\
\text { monocytogenes }\end{array}$ & In vitro & [83] \\
\hline & & Campylobacter coli, Campylobacter jejuni & In vitro & {$[84]$} \\
\hline & & Helicobacter pylori & In vitro & {$[85]$} \\
\hline & & Escherichia coli & In vitro & {$[86]$} \\
\hline \multirow{3}{*}{$\begin{array}{l}\text { Flavan-3- } \\
\text { ols }\end{array}$} & Catechin & Candida albicans & In vitro & [88] \\
\hline & & Helicobacter pylori & In vitro & [86] \\
\hline & & Escherichia coli & In vitro & [87] \\
\hline \multirow[t]{3}{*}{ Flavanones } & Hespertin & Staphylococcus aureus; Candida albicans & In vitro & [89] \\
\hline & Naringenin & Lactococcus lactis & In vitro & {$[90]$} \\
\hline & & Staphylococcus aureus & $\begin{array}{l}\text { In vitro } \\
\text { In vivo (mice) }\end{array}$ & [91] \\
\hline \multirow[t]{3}{*}{ Flavones } & Apigenin & $\begin{array}{l}\text { Pseudomonas aeruginosa, Salmonella } \\
\text { typhimurium, Proteus mirabilis, Klebsiella } \\
\text { pneumoniae and Enterobacter aerogenes }\end{array}$ & In vitro & {$[92]$} \\
\hline & & $\begin{array}{l}\text { Staphylococcus epidermis, Bacillus subtili, } \\
\text { Saccharomyses cerevisiae }\end{array}$ & In vitro & [93] \\
\hline & Luteolin & $\begin{array}{l}\text { Staphylococcus epidermis, Bacillus subtili, } \\
\text { Saccharomyses cerevisiae }\end{array}$ & In vitro & [93] \\
\hline \multirow[t]{2}{*}{ Flavonols } & Keampferol & Enterococcus faecalis & In vitro & [94] \\
\hline & Rutin & $\begin{array}{l}\text { Acinetobacter baumannii, Staphylococcus aureus, } \\
\text { Enterococcus faecalis, Bacillus subtilis. }\end{array}$ & In vitro & {$[95]$} \\
\hline \multirow[t]{3}{*}{ Isoflavones } & Genistein & Vibrio harveyi & In vitro & {$[96]$} \\
\hline & & Bacillus anthracis & In vitro & {$[97]$} \\
\hline & & Klebsiella pneumonia, Salmonella typhi & In vitro & [98] \\
\hline \multirow[t]{5}{*}{ Stilbenes } & Resveratrol & Enterococcus faecalis & In vitro & {$[94]$} \\
\hline & & Candida albican & In vitro & {$[102]$} \\
\hline & & Campylobacter spp, Arcobacter butzleri & In vitro & [99] \\
\hline & & $\begin{array}{l}\text { Saccharomyces. cerevisiae; Aspergillus ninger, } \\
\text { Penicillum. expansum }\end{array}$ & In vitro & {$[100]$} \\
\hline & & Helicobacter pylori & In vitro & {$[101]$} \\
\hline
\end{tabular}


Table 3. Examples of phenolic compounds with anti-inflammatory activity.

\begin{tabular}{|c|c|c|c|c|}
\hline \multicolumn{2}{|c|}{ Phenolic compound } & \multirow{2}{*}{$\begin{array}{l}\text { Effect } \\
\text { Inhibition of tumor necrosis factor } \alpha \text { and } \\
\text { interleukin- } 6 \text { in mouse macrophages }\end{array}$} & \multirow{2}{*}{$\begin{array}{l}\text { Type of assay } \\
\text { In vitro }\end{array}$} & \multirow{2}{*}{$\begin{array}{l}\text { Reference } \\
{[103]}\end{array}$} \\
\hline Flavanone & Hesperetin & & & \\
\hline \multirow[t]{6}{*}{ Flavones } & Apigenin & $\begin{array}{l}\text { Inhibition of NF- } \kappa \mathrm{B} \text { transcriptional } \\
\text { activation }\end{array}$ & In vivo (mice) & {$[104]$} \\
\hline & \multirow[t]{5}{*}{ Luteolin } & Inhibition of TNF- $\alpha$ & In vivo (mice) & {$[105]$} \\
\hline & & $\begin{array}{l}\text { Inhibition of NF- } \kappa B \text { transcriptional } \\
\text { activation }\end{array}$ & In vivo (mice) & [104] \\
\hline & & $\begin{array}{l}\text { Reduction of nitric oxide synthase } \\
\text { expression }\end{array}$ & In vitro & {$[106]$} \\
\hline & & $\begin{array}{l}\text { Downregulation of TLR4, TLR5, NF- } \mathrm{BB}, \mathrm{p}- \\
\text { p38MAPK }\end{array}$ & In vivo (rats) & {$[107]$} \\
\hline & & Prevention of the activity of Hsp90 & $\begin{array}{l}\text { In vitro } \\
\text { In vivo (mice) }\end{array}$ & [108] \\
\hline
\end{tabular}

NF- $\kappa \mathrm{B}$ - factor nuclear kappa B; TNF- $\alpha$ - tumor necrosis factor $\alpha$; TLR4 - toll-like receptor 4;TLR5 toll-like receptor 5; p-p38MAPK - phosphor-p38 MAPK; Hsp90 - heat shock protein 90. 
Table 4. Examples of phenolic compounds with antitumoral effects.

\begin{tabular}{|c|c|c|c|c|}
\hline \multicolumn{2}{|c|}{ Phenolic compound } & \multirow{2}{*}{$\begin{array}{l}\text { Type of tumor } \\
\text { Leukemia }\end{array}$} & \multirow{2}{*}{$\begin{array}{l}\text { Type of assay } \\
\text { In vitro (human cell lines) }\end{array}$} & \multirow{2}{*}{$\begin{array}{l}\text { Reference } \\
{[109]}\end{array}$} \\
\hline Phenolic & Gallic acid & & & \\
\hline acids & & Glioma & $\begin{array}{l}\text { In vitro (human cell lines) } \\
\text { In vitro (murine cell lines) }\end{array}$ & {$[110]$} \\
\hline & & Lung carcinoma & $\begin{array}{l}\text { In vitro (human cell lines) } \\
\text { In vitro (murine cell lines) }\end{array}$ & {$[111]$} \\
\hline \multirow[t]{3}{*}{ Anthocyanins } & Cyanidin & Colorectal carcinoma & In vitro (human cell lines) & [112] \\
\hline & Delphinidin & Prostate carcinoma & $\begin{array}{l}\text { In vitro (human cell lines) } \\
\text { In vitro (murine cell lines) }\end{array}$ & {$[113]$} \\
\hline & & Colorectal carcinoma & In vitro (human cell lines) & {$[112]$} \\
\hline \multirow[t]{2}{*}{ Flavan-3-ols } & Catechin & Breast cancer (MCF-7) & In vitro (human cell lines) & [115] \\
\hline & & Melanoma & $\begin{array}{l}\text { In vitro (human cell lines) } \\
\text { In vitro (murine cell lines) }\end{array}$ & {$[114]$} \\
\hline \multirow[t]{3}{*}{ Flavanones } & Hespertin & Breast carcinoma & In vitro (human cell lines) & {$[116]$} \\
\hline & & Cervical carcinoma & In vitro (human cell lines) & [117] \\
\hline & Naringenin & Skin carcinoma & In vitro (human cell lines) & [118] \\
\hline \multirow[t]{9}{*}{ Flavones } & Apigenin & Lymphoma & In vitro (human cell lines) & [119] \\
\hline & & Pancreatic cancer & In vitro (human cell lines) & {$[120]$} \\
\hline & Luteolin & Colon carcinoma & In vitro (human cell lines) & {$[121]$} \\
\hline & & Non-small cell lung cancer & In vitro (human cell lines) & {$[122]$} \\
\hline & & $\begin{array}{l}\text { Hepatocellular carcinoma } \\
\text { (HepG2 and Bel7402) }\end{array}$ & In vitro (human cell lines) & {$[123]$} \\
\hline & & Non-small cell lung cancer & In vivo (mouse cell lines) & {$[124]$} \\
\hline & & $\begin{array}{l}\text { Breast cancer (MDA-MB- } \\
\text { 231) }\end{array}$ & In vitro (human cell lines) & {$[127]$} \\
\hline & & Glioblastoma (GBM 8401) & In vitro (human cell lines) & {$[125]$} \\
\hline & & $\begin{array}{l}\text { Breast cancer (MDA-MB- } \\
231)\end{array}$ & $\begin{array}{l}\text { In vitro (human cell lines) } \\
\text { In vitro (mouse cell lines) }\end{array}$ & {$[126]$} \\
\hline \multirow[t]{4}{*}{ Flavonols } & Kaempferol & $\begin{array}{l}\text { Hepatocarcinoma } \\
\text { Pancreatic carcinoma }\end{array}$ & In vitro (human cell lines) & {$[131,132]$} \\
\hline & & Breast cancer (MCF-7) & $\begin{array}{l}\text { In vitro (human cell lines) } \\
\text { In vivo (female mice) }\end{array}$ & {$[134]$} \\
\hline & & Ovarian cancer & In vitro (human cell lines) & [133] \\
\hline & Quercetin & $\begin{array}{l}\text { Gastric adenocarcinoma } \\
\text { Hepatocellular carcinoma } \\
\text { Leukemia } \\
\text { Lung adenocarcinoma } \\
\text { Prostate cancer }\end{array}$ & In vitro (human cell lines) & [128-130] \\
\hline Isoflavones & Genistein & Prostate carcinoma & $\begin{array}{l}\text { In vitro (human cell lines) } \\
\text { In vivo (murine models) }\end{array}$ & {$[135,136]$} \\
\hline Stilbenes & Resveratrol & $\begin{array}{l}\text { Leukemia } \\
\text { Neuroblastoma } \\
\text { Pancreatic carcinoma } \\
\text { Breast carcinoma } \\
\text { Prostate carcinoma } \\
\text { Renal carcinoma } \\
\end{array}$ & In vitro (human cell lines) & {$[137,138]$} \\
\hline
\end{tabular}


Table 5. Examples of phenolic compounds with hepatoprotective effects.

\begin{tabular}{|c|c|c|c|c|}
\hline \multicolumn{2}{|c|}{ Phenolic compound } & Effect & Type of assay & Reference \\
\hline \multirow[t]{4}{*}{$\begin{array}{l}\text { Phenolic } \\
\text { acids }\end{array}$} & Caffeic acid & $\mathrm{GI}_{50}=52.06 \mu \mathrm{g} / \mathrm{mL}$ & $\begin{array}{l}\text { In vitro (HepG2 } \\
\text { cells) }\end{array}$ & {$[139]$} \\
\hline & $\begin{array}{l}\text { Chlorogenic } \\
\text { acid }\end{array}$ & $\downarrow$ HBV DNA replication & In vitro & {$[141]$} \\
\hline & Gallic acid & $\downarrow \mathrm{AST}, \downarrow \mathrm{ALT}, \downarrow \mathrm{TB}, \downarrow \mathrm{GGT}$ & In vivo (rats) & {$[142]$} \\
\hline & & $\begin{array}{l}\uparrow \mathrm{SOD}, \uparrow \mathrm{CAT}, \uparrow \mathrm{GSH}, \uparrow \text { lipase }, \uparrow \alpha \text {-amylase, } \\
\uparrow \mathrm{Alb}, \downarrow \text { ALP }, \downarrow \mathrm{AST}, \downarrow \text { ALT }, \downarrow \text { triacylglycerol, } \\
\downarrow \mathrm{TB}, \downarrow \text { glucose }, \downarrow \text { cholesterol }\end{array}$ & In vivo (rats) & [140] \\
\hline \multirow[t]{2}{*}{ Flavanones } & Hespertin & $\downarrow$ AST,$\downarrow$ ALT,$\downarrow$ MDA, $\uparrow$ SOD,$\uparrow$ GSH-Px & In vivo (mice) & [143] \\
\hline & Narigenin & $\downarrow$ PGT,$\downarrow$ ALP,$\uparrow \gamma$-GTP & In vivo (rats) & [144] \\
\hline \multirow[t]{4}{*}{ Flavones } & Apigenin & $\begin{array}{l}\downarrow \text { SGOT }, \downarrow \text { SGPT, } \downarrow \text { ALP }, \downarrow \text { TG }, \downarrow \text { TC }, \downarrow \text { LDL, } \\
\downarrow \text { BUN }, \downarrow \text { creatinine }, \downarrow T B, \uparrow \text { HDL }\end{array}$ & $\begin{array}{l}\text { In vivo (wistar } \\
\text { rats) }\end{array}$ & {$[146]$} \\
\hline & & $\mathrm{GI}_{50}=52.06 \mu \mathrm{g} / \mathrm{mL}$ & $\begin{array}{l}\text { In vitro (HepG2 } \\
\text { cells) }\end{array}$ & {$[139]$} \\
\hline & Luteolin & $\begin{array}{l}\downarrow \text { SGOT }, \downarrow \text { SGPT }, \downarrow \text { ALP }, \downarrow \text { TG }, \downarrow \text { TC }, \downarrow \text { LDL }, \\
\downarrow \text { BUN }, \downarrow \text { creatinine }, \downarrow T B, \uparrow \text { HDL }\end{array}$ & $\begin{array}{l}\text { In vivo (wistar } \\
\text { rats) }\end{array}$ & {$[146]$} \\
\hline & & $\mathrm{GI}_{50}=85.8$ and $20.2 \mu \mathrm{M}$ & $\begin{array}{l}\text { In vitro (Hep } \mathrm{G} 2 \\
\text { cells) }\end{array}$ & {$[145]$} \\
\hline \multirow[t]{7}{*}{ Flavonols } & Isorhamnetin & $\downarrow$ AST,$\downarrow$ ALT,$\downarrow$ TB,$\downarrow$ GGT & In vivo (rats) & [142] \\
\hline & Kaempferol & $\downarrow \mathrm{AST}, \downarrow \mathrm{ALT}, \downarrow \mathrm{TB}, \downarrow \mathrm{GGT}$ & In vivo (rats) & [142] \\
\hline & & $\mathrm{GI}_{50}=52.06 \mu \mathrm{g} / \mathrm{mL}$ & $\begin{array}{l}\text { In vitro (HepG2 } \\
\text { cells) }\end{array}$ & [139] \\
\hline & Myricetin & $\downarrow$ AST,$\downarrow$ ALT,$\downarrow$ TB,$\downarrow$ GGT & In vivo (rats) & [142] \\
\hline & Quercetin & $\downarrow \mathrm{AST}, \downarrow \mathrm{ALT}, \downarrow \mathrm{MDA}, \uparrow \mathrm{SOD}, \uparrow \mathrm{GSH}-\mathrm{Px}$ & In vivo (mice) & {$[143]$} \\
\hline & & $\downarrow \mathrm{AST}, \downarrow \mathrm{ALT}, \downarrow \mathrm{TB}, \downarrow \mathrm{GGT}$ & In vivo (rats) & [142] \\
\hline & Rutin & $\downarrow \mathrm{ALP}, \downarrow \mathrm{ALT}, \downarrow \mathrm{AST}$ & $\begin{array}{l}\text { In vivo (wistar } \\
\text { rats) }\end{array}$ & {$[147]$} \\
\hline
\end{tabular}

Alb - Albumin; ALP - alkaline phosphatase; ALT - Alanine transaminase; AST - Aspartate transaminase; BUN - Blood urea nitrogen; CAT - Catalase; DNA - deoxyribonucleic acid; GI 50 - Sample concentration that inhibited $50 \%$ of the net cell growth; GGT - $\gamma$-glutamyltransferase; GSH - reduced glutathione; GSH-Px - Glutathione peroxidase; HBV - Hepatitis B; HDL - High-density lipoprotein; HepG2 - hepatocellular carcinoma line; LDL - Low-density lipoprotein; MDA - Malondialdehyde; PGT - Glutamic-pyruvic transaminase; SGPT - Serum glutamate pyruvate transaminase; SOD - Superoxide dismutase; SGOT - Serum glutamate oxaloacetate transaminase; TB - Total bilirubin; TC - Total cholesterol; TG - triglyceride; $\gamma$-GTP $-\gamma$-glutamyl transpeptidase. 
Table 6. Phenolic compounds from food sources with reported biological effects mainly related with antioxidant capacity and prevention of cardiovascular disease and cancer.

\begin{tabular}{|c|c|c|c|}
\hline Phenolic compound & & Source & Reference \\
\hline Phenolic acids & Gallic acid & Red wine & {$[175]$} \\
\hline Anthocyanins & $\begin{array}{l}\text { Cyanidin } \\
\text { Pelargonidin } \\
\text { Peonidin } \\
\text { Delphinidin } \\
\text { Malvidin } \\
\end{array}$ & Blackberry, blueberry, black grape, cherry, strawberry, red wine, plum & {$[226,227]$} \\
\hline Condensed tannins & Procyanidin & Red wine, chocolate, cranberry juice and apples & {$[228]$} \\
\hline Flavan-3-ols & Catechin & Fruits, vegetables, chocolate, lentil, green and black tea, wine, grapes and ginkgo & {$[184,229-234]$} \\
\hline Flavanones & $\begin{array}{l}\text { Hespertin } \\
\text { Naringenin }\end{array}$ & Orange, grapefruit and lemon juices & {$[190,192]$} \\
\hline Flavones & $\begin{array}{l}\text { Apigenin } \\
\text { Luteolin }\end{array}$ & Parsley, celery, capsicum pepper and grape & {$[184,192]$} \\
\hline Flavonols & $\begin{array}{l}\text { Quercetin } \\
\text { Kaempferol }\end{array}$ & Fruits, vegetables, and beverages such as tea and red wine & $\begin{array}{l}{[184,235-237]} \\
{[177,178,238,239]}\end{array}$ \\
\hline Isoflavones & Genistein & Soy & {$[240,241]$} \\
\hline Stilbenes & Resveratrol & Legumes, grapes, red wine, soy, peanuts and peanut products & {$[187,189,242-245]$} \\
\hline
\end{tabular}


Table 7. Phenolic compounds used as nutraceuticals or bioactive compounds in functional foods.

\begin{tabular}{|c|c|c|c|c|}
\hline $\begin{array}{l}\text { Phenolic } \\
\text { compound }\end{array}$ & Source & Application & Bioactivity & Reference \\
\hline Phenolic acids & Commercial & Infant cereals & $\begin{array}{l}\text { Antioxidant properties and } \\
\text { aroma }\end{array}$ & [246] \\
\hline Anthocyanins & Cranberry (Vaccinium macrocarpon Ait.) & Nutraceutical capsules & Antioxidant activity & [247] \\
\hline Isoflavones & Soy (Glycine max L.) & Dietary supplements & Antimenopausial sympthoms & [248] \\
\hline \multirow[t]{14}{*}{ Phenolic extracts } & Blackberry (Rubus ulmifolius Schott) flowers & Yogurt & $\begin{array}{l}\text { Antioxidant and antimicrobial } \\
\text { activity }\end{array}$ & [202] \\
\hline & Borage (Borago officinalis L.) & Fresh Pasta & Antimicrobial activity & {$[208]$} \\
\hline & Chamomile (Matricaria recutita L.) flowers & $\begin{array}{l}\text { Cottage chesse and } \\
\text { yogurt }\end{array}$ & $\begin{array}{l}\text { Antioxidant and antimicrobial } \\
\text { activity }\end{array}$ & {$[54,206]$} \\
\hline & Fennel (Foeniculum vulgare Mill.) aerial parts & $\begin{array}{l}\text { Cottage chesse and } \\
\text { yogurt }\end{array}$ & $\begin{array}{l}\text { Antioxidant and antimicrobial } \\
\text { activity }\end{array}$ & {$[55,206]$} \\
\hline & Garcinia (Garcinia cowa Roxb) fruits & Bread & Antioxidant activity & {$[199]$} \\
\hline & Grape seed (Vitis vinifera L.) & Yogurt & Antioxidant activity & {$[201]$} \\
\hline & Green tea (Cammelia sinensis L.) & Bread & Antioxidant activity & {$[200]$} \\
\hline & Guava (Psidium guajava) flower & Bread melanoidins & Antioxidant activity & [207] \\
\hline & Pomegranate (Punica granatum L.) fruits & Yogurt and pasta & Antioxidant activity & {$[196,197]$} \\
\hline & Pomegranate (Punica granatum L.) peels & Ice cream & $\begin{array}{l}\text { Antioxidant and aglucosidase } \\
\text { inhibitory activities }\end{array}$ & {$[198]$} \\
\hline & $\begin{array}{l}\text { Residues from brewing } \\
\text { industry }\end{array}$ & Meat & $\begin{array}{l}\text { Antioxidant and antimicrobial } \\
\text { activity }\end{array}$ & {$[249]$} \\
\hline & Rosemary (Rosmarinus officinalis L.) & Cottage cheese & Antioxidant activity & {$[205]$} \\
\hline & $\begin{array}{l}\text { Suillus luteus (L.: Fries) Gray and Coprinopsis atramentaria (Bull.) } \\
\text { Redhead, Vilgalys \& Moncalvo }\end{array}$ & Cottage chesse & Antioxidant activity & {$[204]$} \\
\hline & Veronicas (Veronica montana L.) & Cream cheese & Antibacterial activity & {$[203]$} \\
\hline
\end{tabular}




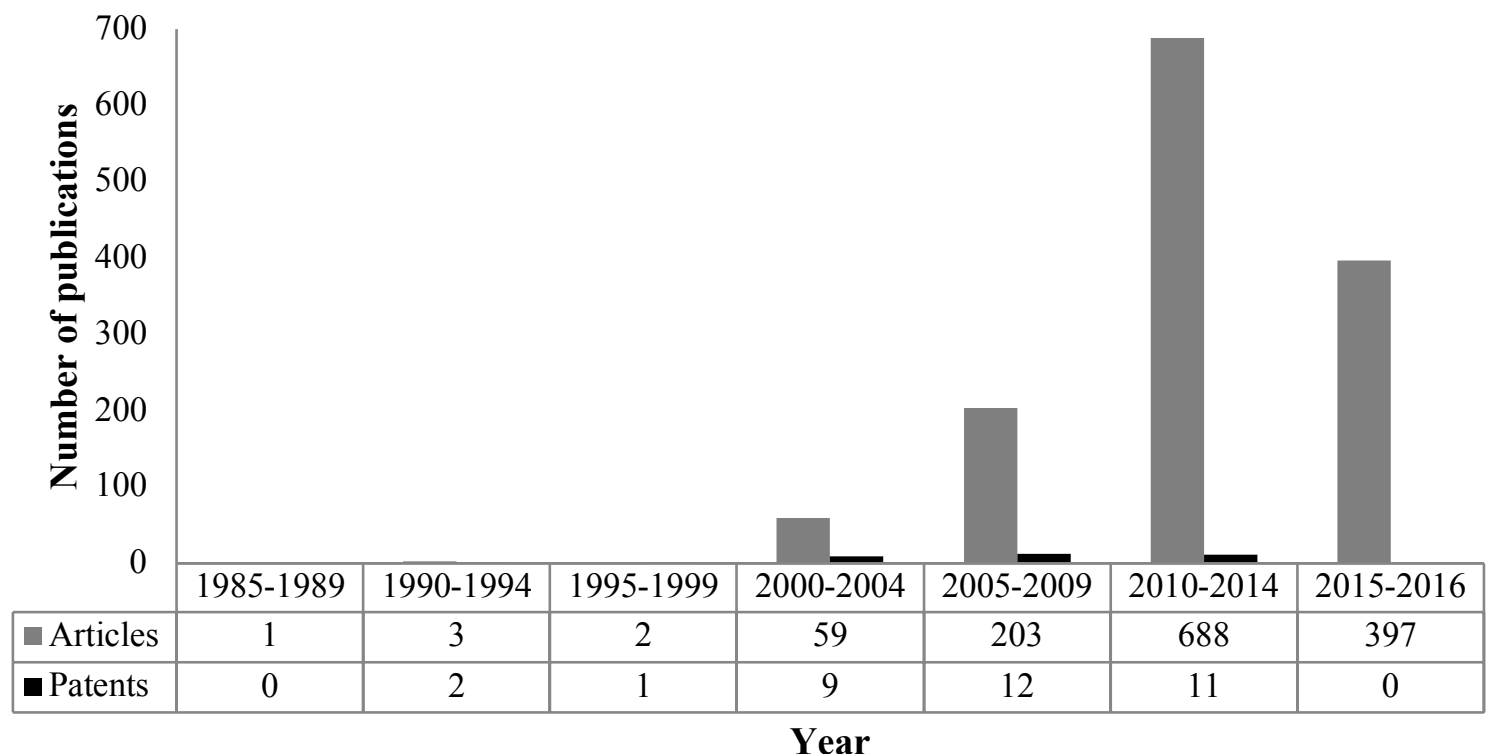

Figure 1. Number of research articles and reviews, and patents published in the period from 1985 to 2016 regarding functional foods and phenolic compounds (obtained on web of science, July 2016; keyword: functional food and phenolic compounds). 
Flavonoids<smiles>O=c1cc(-c2ccccc2)oc2ccccc12</smiles><smiles>O=C1CC(c2ccccc2)Oc2ccccc21</smiles>

Isoflavones<smiles>O=c1c(-c2ccccc2)coc2ccccc12</smiles>
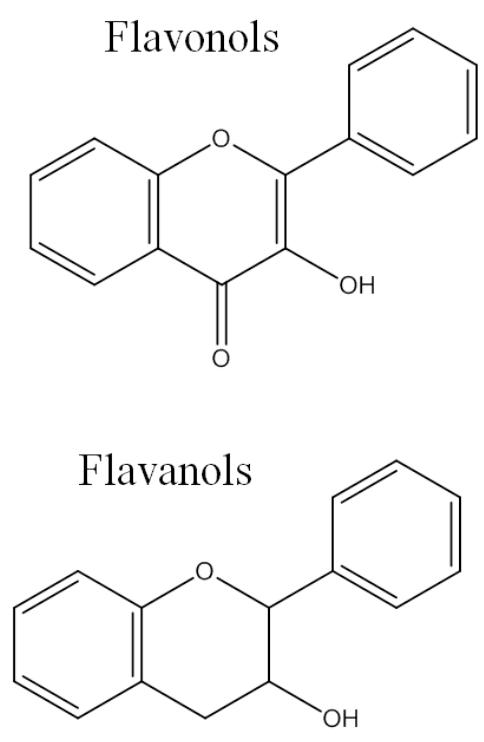

Anthocyanins<smiles></smiles>

Non-Flavonoids

Phenolic acids Hydroxybenzoic acid<smiles>O=C(O)c1ccccc1</smiles>

Hydroxyccinamic acid
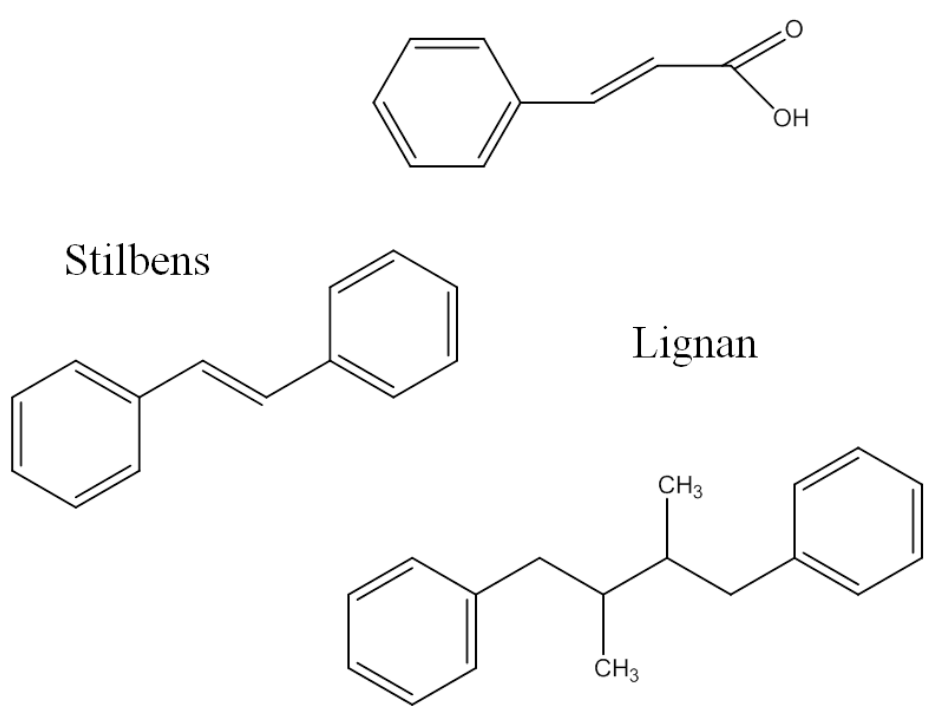

Figure 2. Chemical structure of subclasses of the flavonoids and non-flavonoids. 


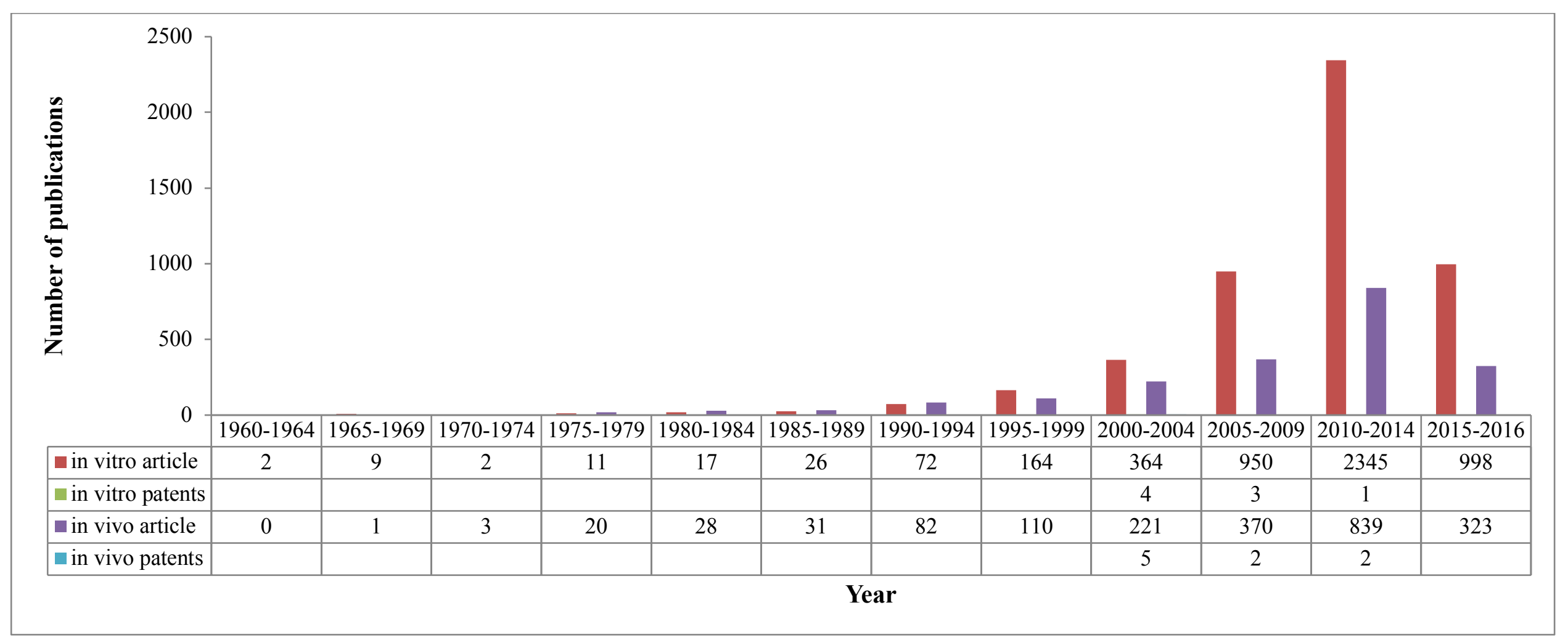

Figure 3. Number of research articles and reviews, and patents published in the period from 1985 to 2015 regarding phenolic compounds and in vitro or in vivo assays (obtained on web of science, July 2016; keyword: phenolic compounds and in vitro; phenolic compounds and in vivo). 


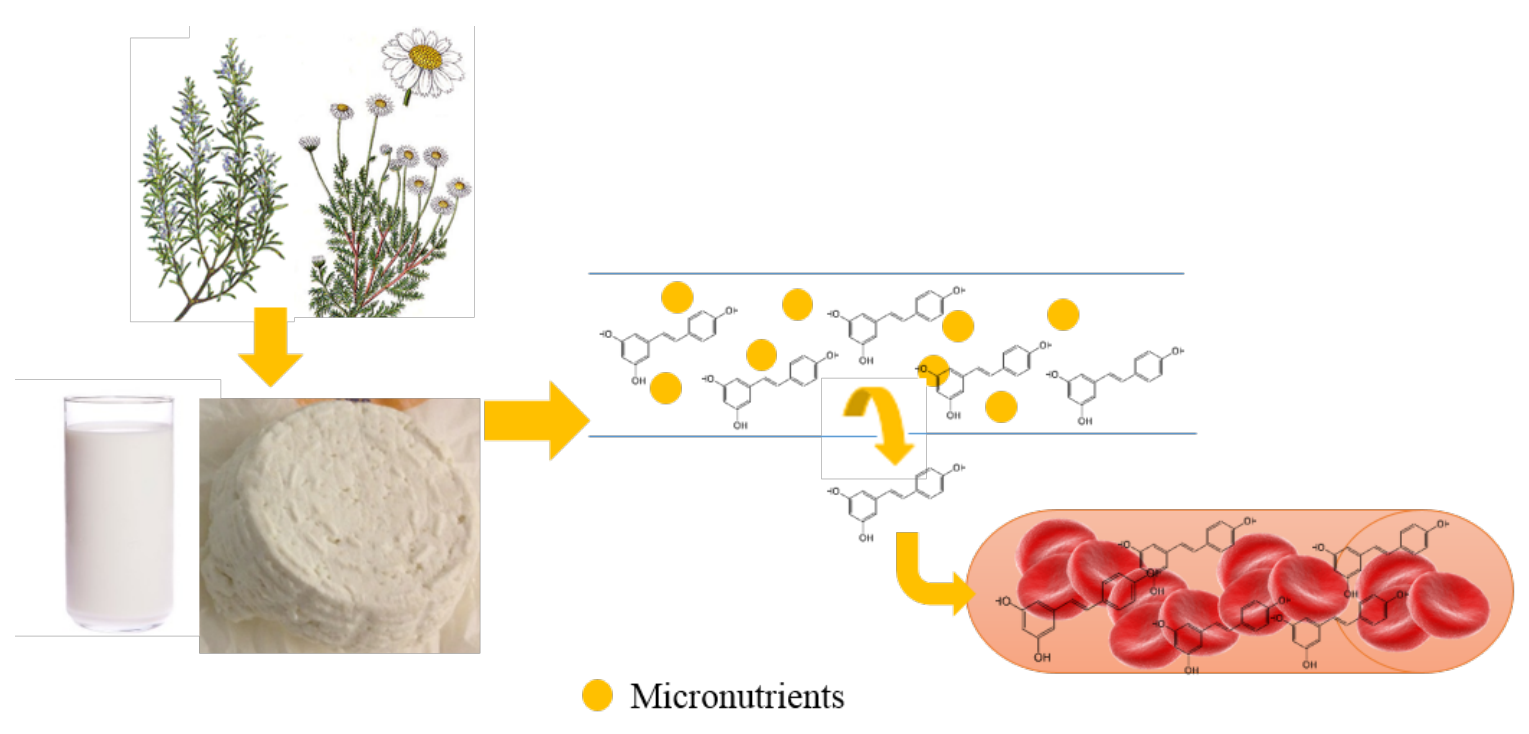

Figure 4. Beneficial effects of phenolic compounds. $\downarrow$ ROS

$\downarrow$ Lipoperoxidation

$\checkmark$ Oncogene expression

$\downarrow$ Attacks on DNA

Among other mechanisms

Prevention of: Cardiovascular diseases Neurological diseases Pulmonary diseases Cancer

Rheumatic diseases Metabolic diseases Infectious diseases 